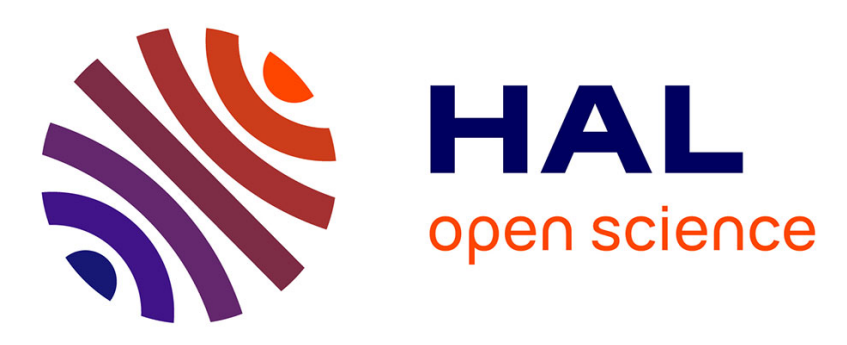

\title{
Resolution of $\beta$-aminophosphines with chiral cyclopalladated complexes
}

Jean-Michel Camus, Patricia Roy Garcia, Jacques Andrieu, Philippe Richard, Rinaldo Poli

\section{- To cite this version:}

Jean-Michel Camus, Patricia Roy Garcia, Jacques Andrieu, Philippe Richard, Rinaldo Poli. Resolution of $\beta$-aminophosphines with chiral cyclopalladated complexes. Journal of Organometallic Chemistry, 2005, 690 (6), pp.1659-1668. 10.1016/j.jorganchem.2005.01.023 . hal-03278295

\section{HAL Id: hal-03278295 \\ https://hal.science/hal-03278295}

Submitted on 6 Jul 2021

HAL is a multi-disciplinary open access archive for the deposit and dissemination of scientific research documents, whether they are published or not. The documents may come from teaching and research institutions in France or abroad, or from public or private research centers.
L'archive ouverte pluridisciplinaire $\mathbf{H A L}$, est destinée au dépôt et à la diffusion de documents scientifiques de niveau recherche, publiés ou non, émanant des établissements d'enseignement et de recherche français ou étrangers, des laboratoires publics ou privés. 


\title{
Resolution of $\beta$-aminophosphines with chiral cyclopalladated complexes
}

\author{
Jean-Michel Camus ${ }^{\mathrm{a}}$, Patricia Roy García ${ }^{\mathrm{a}}$, Jacques Andrieu*a, \\ Philippe Richard ${ }^{\mathrm{a}}$ and Rinaldo Poli ${ }^{\mathrm{a}, \mathrm{b}}$
}

\author{
${ }^{\mathrm{a}}$ Laboratoire de Synthèse et Electrosynthèse Organométalliques, UMR 5188 CNRS, \\ Université de Bourgogne, Faculté des Sciences Mirande, \\ 9, avenue Alain Savary, 21078 Dijon, France \\ ${ }^{b}$ Laboratoire de Chimie de Coordination, UPR CNRS 8241, \\ 205 route de Narbonne, 31077 Toulouse, France.
}

Proofs to: Dr Jacques Andrieu

Laboratoire de Synthèse et Electrosynthèse Organométalliques, UMR 5188 CNRS, Université de Bourgogne, Faculté des Sciences Mirande,

9, avenue Alain Savary, 21078 Dijon, France

e-mail : Jacques.Andrieu @u-bourgogne.fr

\section{Key words :}

Aminophosphines, $\mathrm{P}, \mathrm{N}$ ligands, racemic resolution, chiral palladium complexes, $\mathrm{X}$-ray structures 
Pictogram for contents page

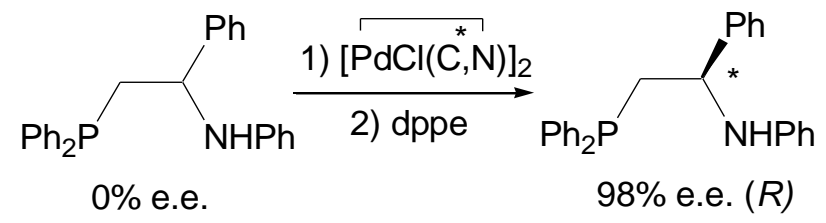

\section{Synopsis for contents page}

A chiral $\beta$-aminophosphine has been isolated by resolving its racemic mixture with a palladacycle complex chiral agent. Its absolute configuration has been determined from the X-ray structure analysis of the related palladium dichloride complex. 


\begin{abstract}
Resolution of the racemic chiral $\beta$-aminophosphines $\mathrm{Ph}_{2} \mathrm{PCH}_{2} \mathrm{CH}(\mathrm{Ph}) \mathrm{NH}(\mathrm{Ar})\left(\mathbf{L}^{1}\right.$ for $\mathrm{Ar}=\mathrm{C}_{6} \mathrm{H}_{5}$ and $\mathbf{L}^{2}$ for $\mathrm{Ar}=2,6-\mathrm{C}_{6} \mathrm{H}_{3}{ }^{\mathrm{i}} \mathrm{Pr}_{2}$ ) has been investigated by use of different cyclopalladated complexes as chiral agents. The resulting complexes afford diastereomeric adducts in a 1:1 ratio. After successive crystallizations from ethanol, a d.e. of 98\% was achieved for one amino-phosphine palladium complex, while no significant d.e. was obtained after crystallizations from chlorinated solvents. The X-ray structure analysis has pointed out intermolecular hydrogen interactions $\mathrm{N}-\mathrm{H}$... Cl between the P,N ligand and the chloride ion, which are responsible for the formation and stabilization of the diastereomeric adducts. Thus, the use of oxygenated solvents cancels such hydrogen interactions by their stronger donor character and makes the diastereomers separation possible, allowing to isolate the optically pure $(R)-\mathrm{Ph}_{2} \mathrm{PCH}_{2} \mathrm{CH}(\mathrm{Ph}) \mathrm{NH}(\mathrm{Ph}) \mathbf{L}^{\mathbf{1}}$ of which the absolute configuration has been determined from the X-ray structure analysis of the related palladium dichloride complex.
\end{abstract}

\title{
Introduction
}

Since the last decade, P,N ligands, specifically amino-phosphines, have found numerous applications in the field of homogeneous catalysis with catalysts based on $\mathrm{Pd}^{1}, \mathrm{Pt}^{2}, \mathrm{Ru}^{3}, \mathrm{Rh}^{1,4}$ or $\mathrm{Ir}^{5}$ In addition, chiral versions of these ligands exhibit interesting properties in asymmetric catalysis. For instance, the selective P,N chelation by the chiral phosphinediamine $(S, S)-\left[{ }^{i} \operatorname{PrP}\left\{o-\mathrm{C}_{6} \mathrm{H}_{4}-\mathrm{CH}\left(\mathrm{CH}_{3}\right) \mathrm{N}\left(\mathrm{CH}_{3}\right)_{2}\right\}_{2}\right]$ induces an effective chiral field in a rhodium complex leading to high enantioselectivities in acrylic acid hydrogenation. ${ }^{4}$ As another example, the nature of the $\mathrm{N}$-substituent of other amino-phosphines chelates $(S)-\left[\mathrm{Ph}_{2} \mathrm{CH}_{2} \mathrm{CH}\left({ }^{\mathrm{i} P r}\right) \mathrm{NR}^{1} \mathrm{R}^{2}\right]$ (with $\mathrm{R}^{1}=\mathrm{Me}$ or $\mathrm{Ph}$ and $\mathrm{R}^{2}=\mathrm{Ph}$ or ${ }^{\mathrm{i}} \mathrm{Pr}$ ) affects the enantioselectivity in palladium-catalysed allylic alkylation. ${ }^{6}$

Generally, the synthesis of achiral amino-phosphines involves one or two steps ${ }^{7-9}$. In the same way, the racemic chiral $\beta$-amino-phosphines $\mathbf{L}^{\mathbf{1}}$ and $\mathbf{L}^{\mathbf{2}}$ are also obtained in one step by reaction between the $\mathrm{Ph}_{2} \mathrm{PCH}_{2}{ }^{-}$anion and imines ${ }^{10}$, see Chart1.

\section{$<$ Insert Chart 1>}

Nevertheless, the extension to the preparation of chiral $\beta$-amino-phosphines in an enantiomerically pure form requires long and tedious steps in order to introduce a stereogenic center in a defined absolute configuration. The different strategies are based either on the use of chiral amino-acids or L-valine ${ }^{11-13}$ as starting chiral compound, or on the use of a chiral saturated N- 
heterocycle, ${ }^{14}$ or again on stereoselective additions to optically pure imines ${ }^{15}$ or substituted aziridines ${ }^{16}$. These multistep syntheses lead to a single enantiomer of the similar ligands $\mathrm{Ph}_{2} \mathrm{PCH}_{2} \mathrm{CH}\left({ }^{\mathrm{i}} \mathrm{Pr}\right) \mathrm{NPh}_{2}{ }^{12}, \mathrm{Ph}_{2} \mathrm{PCH}_{2} \mathrm{CH}\left({ }^{\mathrm{i}} \mathrm{Pr}\right) \mathrm{NH}^{\mathrm{i} P r}$ and $\mathrm{Ph}_{2} \mathrm{PCH}_{2} \mathrm{CH}\left({ }^{\mathrm{i}} \mathrm{Pr}\right) \mathrm{NH}_{2}{ }^{6}$ from L-valinol (derived from L-Valine by reduction), with global yields between 17 and $25 \%$. The access to both ligands $\mathbf{L}^{1}$ and $\mathbf{L}^{2}$ in an optically pure form in a shorter way than those mentioned above and/or by another higher yield procedure would be desirable for application to enantioselective catalytic processes.

With specific reference to palladium catalyzed asymmetric allylic allylation, we have recently studied the cationic complexes $\left[\mathrm{Pd}\left(\eta^{3}-\mathrm{CH}_{2} \mathrm{CHCHR}\right)\left\{\mathrm{Ph}_{2} \mathrm{PCH}_{2} \mathrm{CH}(\mathrm{Ph}) \mathrm{NH}(\mathrm{Ar})-\kappa^{2}-P, N\right\}\right]^{+}$ (with $\mathrm{R}=\mathrm{Me}, \mathrm{Ph}, \mathrm{Ar}=\mathrm{Ph}, 2,6-\mathrm{C}_{6} \mathrm{H}_{3}{ }^{\mathrm{i}} \mathrm{Pr}_{2}$ ) and reported that the change of $\mathrm{N}$-substituent modifies significantly the endo/exo ratio without changing the trans- $\mathrm{P} /$ cis- $\mathrm{P}$ ratio when $\mathrm{R}=\mathrm{Me}$. For the phenylallyl Pd(II) complexes, on the other hand, the opposite phenomenon was observed (see Scheme 1$)^{17}$. Under the assumption that the exo and endo isomers react at the same rate with a nucleophile, the endo/exo ratio could then allow to control the enantioselectivity during the nucleophile addition, when using enantiomerically pure versions of the chiral amino-phosphine ligand.

\section{$<$ Insert Scheme 1>}

In addition to the above mentioned asymmetric syntheses, optically pure P,N ligands can also be obtained by racemic resolution via specific resolving agents. The phosphorus atom has basic properties, but the general organic methods employing tartaric or camphrosulfonic acid cannot be applied because of its air sensitivity. A specific procedure for the resolution of tertiary phosphines ${ }^{18-}$ ${ }^{20}$ di-phosphines ${ }^{21,22}$ or hydroxy-phosphines ${ }^{23,24}$ is based on the use of an optically active palladium metallacycle complex, which is available on a gram scale, as chiral agent. We wished to extend this procedure to heteroditopic ligands like the amino-phosphines $\mathbf{L}^{\mathbf{1}}$ and $\mathbf{L}^{\mathbf{2}}$ and report herein the results of our studies.

\section{Results and discussion}

\section{Synthesis of neutral amino-phosphines palladium complexes}

The reaction of the chiral chloro-palladium dimer $(S)-\mathbf{1}$ (prepared by orthometallation of (S)-methylbenzylamine by $\operatorname{Pd}(\text { acetate })_{2}{ }^{25}$ ) with two equivalents of $\mathbf{L}^{\mathbf{1}}$ or $\mathbf{L}^{\mathbf{2}}$ leads to complexes $\mathbf{2}$ and 3, respectively, as a mixture of two diastereomers labelled "a" and "b" (see Scheme 2). 
The ${ }^{31} \mathrm{P}-\mathrm{NMR}$ spectrum shows the presence of two singlets with equal intensity at $\delta=40.45$ and at $40.67 \mathrm{ppm}$ for $\mathbf{2}^{\mathbf{a}, \mathbf{b}}$ (and at $\delta=38.73$ and at $38.51 \mathrm{ppm}$ for $\mathbf{3}^{\mathbf{a}, \mathbf{b}}$ ). The 1:1 diastereomeric ratio was also confirmed by ${ }^{1} \mathrm{H}-\mathrm{NMR}$ integration of $\mathrm{N}$-methyl protons, which is an excellent probe because the chemical shifts for the two diastereomers differ by $0.3 \mathrm{ppm}$ and there is no overlap with others protons of the complex.

\section{Separation of the diastereoisomers}

The first attempt to separate the diastereomers of $\mathbf{2}$ and $\mathbf{3}$ consisted in the use of chromatographic column over silica gel. Different solvent mixtures were tried, but none of them proved suitable. Subsequently, we attempted fractional crystallizations. Yellow crystals of 2 were obtained from a $\mathrm{CH}_{2} \mathrm{Cl}_{2}$ /pentane mixture. Their analysis by ${ }^{1} \mathrm{H}$ and ${ }^{31} \mathrm{P}$ NMR spectroscopy indicated the presence of a 1:1 mixture of the two diastereoisomers, revealing no d.e. for the crystallization process.

One of the crystals of $\mathbf{2}$ was investigated by X-ray diffraction. The crystal data and structure refinement parameters are given in Table 1 . The unit cell is non centro-symmetric (space group P2 1 ) due to the presence of a single enantiomer for each diastereomer. The asymmetric unit contains the two molecules $\mathbf{2}^{\mathbf{a}}$ and $\mathbf{2}^{\mathbf{b}}$, linked to each other by hydrogen bonding, in a 1:1 ratio. An ORTEP view (see Figure 1) shows the $\kappa^{1}$-P-coordination by the amino-phosphine ligand $\mathbf{L}^{\mathbf{1}}$. The geometry around the palladium metal center is slightly distorted square planar, with a trans arrangement of the nitrogen atom from the benzylamine moiety and the phosphorus atom, similar to what was already observed in $\left[\mathrm{PdCl}\left\{\left(\mathrm{PPh}\left({ }^{\mathrm{i}} \mathrm{Pr}\right)(\mathrm{OMe})\right\}(\mathrm{C}, \mathrm{N})\right]\right.$ (with $\mathrm{C}, \mathrm{N}=(R)-\{(1-($ dimethylamino) $)$ thyl $\}-2-$ naphtalenyl). ${ }^{26}$

\section{$<$ Insert Figure 1 and Table 1>}

The five-membered metallacycles adopt an envelope conformation with the $\mathrm{N}(1)$ and $\mathrm{N}(1)^{*}$ atoms at the flap. The bond lengths within the ortho-metallated benzylamine chelate (see Table 2) are quite similar to those found in similar palladium complexes containing other tertiary phosphines. ${ }^{19,26}$ 
The more interesting feature of this structure, however, concerns the dangling NHPh groups of the P,N ligand in both diastereomers, which are involved in intramolecular $\mathrm{N}-\mathrm{H} \ldots \mathrm{Cl}$ hydrogen interactions. Indeed, the separations between the $\mathrm{Cl}$ and $\mathrm{N}$ atoms $\left(\mathrm{Cl}-\mathrm{N}(2), 3.284(7) \AA\right.$; $; \mathrm{Cl}^{*}-\mathrm{N}(2)^{*}$, 3.312(6) Á) are lower than the sum of the NH length and the van der Waals' radii of hydrogen and chloride atoms. ${ }^{27}$ This is consistent with similar intramolecular interactions that we have previously reported for a $\alpha$-aminophosphine rhodium complexes $^{28}$ and for a $\beta$-aminophosphine palladium complex, ${ }^{10}$ and that have been described by other authors for a platinum complex $[\mathrm{PtBr}$ $\left.\left(\mathrm{C}_{6} \mathrm{H}_{4} \mathrm{CH}(\mathrm{Me}) \mathrm{NMe}_{2}-\kappa^{2}-C, N\right)\left(\mathrm{C}_{6} \mathrm{H}_{4} \mathrm{CH}(\mathrm{Me}) \mathrm{NHMe}_{2}-\kappa^{1}-C\right)\right] .{ }^{29}$ In addition, the $\mathrm{Cl}$ and $\mathrm{Cl}^{*}$ chloride atoms are also involved in intermolecular $\mathrm{N}-\mathrm{H}^{\cdots} \mathrm{Cl}$ interactions with the coordinated $\mathrm{NH}$ group of the diastereomeric partner $\left[\mathrm{N}(1) \ldots \mathrm{Cl}^{*}, 3.426(4) \AA \hat{\AA} ; \mathrm{N}\left(1^{*}\right) \ldots \mathrm{Cl}, 3.629(4) \AA ̊ d\right.$, see Figure 1 and Table 2. Consequently, hydrogen interactions with chloride atoms are, at the same time, intra- and intermolecular in the solid state.

In order to establish whether the $\mathrm{N}-\mathrm{H}^{\cdots}{ }^{\cdots} \mathrm{Cl}-\mathrm{Pd}$ interactions are maintained in solution, we have recorded IR spectra for the free ligand and for the complex in solution and in the solid state. In Nujol, the NH absorption bands were found at $3390 \mathrm{~cm}^{-1}$ (for the free ligand) and at 3333 and 3322 $\mathrm{cm}^{-1}$ (for complexes $\mathbf{2}^{\mathbf{a}, \mathbf{b}}$ ). These absorptions are shifted to $3424 \mathrm{~cm}^{-1}$ for the free ligand (in $\mathrm{CH}_{2} \mathrm{Cl}_{2}$ ) and to 3327 and $3317 \mathrm{~cm}^{-1}$ for complexes $2^{\mathbf{a}, \mathbf{b}}$ (in $\mathrm{CHCl}_{3}$ ). In addition, dilution of the $\mathrm{CHCl}_{3}$ solution of $2^{\mathbf{a}, \mathbf{b}}$ by a factor of ten does not yield any shift for the NH absorption bands. These IR observations clearly show that the hydrogen interactions that are present in the solid state are also maintained in solutions of chlorinated hydrocarbons for the Pd complexes, contrary to the free ligand. This suggest that the separation of the diastereomers in chlorinated solvents is probably impossible. On the other hand, solutions in THF yielded NH bands at $3302 \mathrm{~cm}^{-1}$ and at $3358 \mathrm{~cm}^{-1}$ for the free ligand and for complexes $\mathbf{2}^{\mathbf{a}, \mathbf{b}}$, respectively. The higher wavenumber of the $\mathrm{NH}$ absorption band for the Pd complexes suggests that the intermolecular N-H...Cl-Pd hydrogen interactions are replaced by other ones of type N-H...O with the oxygenated solvent. Since the polar solvent seems to inhibit the hydrogen interactions between diastereomers by its stronger donor character, we have decided to crystallize the complexes $\mathbf{2}$ and $\mathbf{3}$ in another Lewis base oxygenated solvent. Indeed, crystallization of $\mathbf{2}$ from hot ethanol yields a diastereomeric excess for the recovered solid. The white powder crushed out from a first crystallization revealed (by ${ }^{1} \mathrm{H}$ and ${ }^{31} \mathrm{P}$ NMR) a 70/30 ratio, i.e. a diastereomeric excess of $40 \%$. This crystallization procedure was repeated and the diastereomeric enrichment for the isolated product was checked by ${ }^{31} \mathrm{P}\left\{{ }^{1} \mathrm{H}\right\} \mathrm{NMR}$ after each crystallization, see Figure 2. 
After three successive crystallizations, an essentially pure diastereomer (labelled arbitrarily as $2^{\mathbf{a}}$ ) was isolated (see Scheme 3) and characterized by a ${ }^{31} \mathrm{P}\left\{{ }^{1} \mathrm{H}\right\}$ singlet resonance at $40.45 \mathrm{ppm}$ and by a ${ }^{1} \mathrm{H}$ doublet resonance at $1.59 \mathrm{ppm}$ for the $\mathrm{N}$-methyl protons. Since the second diastereomer was not detected in the ${ }^{1} \mathrm{H}$ and ${ }^{31} \mathrm{P}\left\{{ }^{1} \mathrm{H}\right\}$ NMR spectra, and since the commercial (S)-1methylbenzylamine is at $98 \%$ e.e., the diastereomeric excess of the isolated complex is estimated at least equal to $98 \%$. The resulting solutions from the crystallizations were evaporated and analyzed by NMR, but unfortunately they always contain significant amounts of both diastereomers. Thus, this method only allows the isolation of one diastereomer with a modest yield of $24 \%$ (relative to the corresponding $\mathbf{L}^{1}$ enantiomer) or $12 \%$ (relative to the $\mathbf{L}^{1}$ racemic mixture). However, the modest yield is comparable to those reported for some multi-step enantio- or diastereo-selective syntheses of chiral P,N ligands (see Introduction).

$<$ Insert Scheme 3>

It is interesting to note that the ancillary $\mathrm{C}, \mathrm{N}$ ligand plays also an important role in diastereomers resolution. The procedure described in Scheme 2 was also used starting from $(S)$-naphtylethylamine $4^{23}$ instead of $\mathrm{N}, \mathrm{N}$-dimethylnaphtylethylamine $(S)$-1, leading to the palladium complexes $\mathbf{5}$, analogues to $\mathbf{2}$, see Scheme 4. After three successive crystallizations in hot ethanol (or after crystallization in different solvent mixture), no d.e. has observed in the isolated product. This result contrasts with the successful use of the palladium complexes prepared from $(S)-4$ and $(R)-4$ to separate the $\mathrm{PhPMe}^{\mathrm{t}} \mathrm{Bu}^{30}$ and QUINAP ${ }^{31}$ enantiomers, while the analogous palladium complexes based on $(S)$-1 had failed. The latter observation was rationalized on the basis of an increased conformational rigidity of the $\mathrm{C}, \mathrm{N}$ chelate, due to the presence of the sterically more demanding QUINAP ligand. ${ }^{31}$ In our case, the amino-phosphine ligand $\mathbf{L}^{\mathbf{1}}$ may be insufficiently sterically demanding to lock the conformations in the corresponding palladium complex.

$<$ Insert Scheme 4>

The separation method discussed above (Scheme 3) has also been applied to complexes $\mathbf{3}^{\mathbf{a}, \mathbf{b}}$. Unfortunately, the highest d.e., obtained after numerous recrystallizations, was only 57\%, equivalent to a $3^{\mathbf{a}} / \mathbf{3}^{\mathbf{b}}$ ratio of $78 / 21$. In order to achieve this separation, the new palladium complexes 6 and 7 have been prepared by abstraction of a chloride anion with $\mathrm{NaPF}_{6}$ from complexes $\mathbf{2}$ and $\mathbf{3}$, see scheme 5 . 
$<$ Insert Scheme 5>

The ${ }^{31} \mathrm{P}\left\{{ }^{1} \mathrm{H}\right\}$ NMR spectrum of complexes 6 and 7 shows a heptuplet at -143.2. ppm for the $\mathrm{PF}_{6}{ }^{-}$anion and two singlets at $\delta=41.32$ and $41.23 \mathrm{ppm}$ (for each diastereomer of $\mathbf{6}$ ) and at $\delta=39.4$ and $39.0 \mathrm{ppm}$ (for each diastereomer of 7). The integration of the $\mathrm{N}$-methyl resonances in the ${ }^{1} \mathrm{H}$ NMR shows that both complexes $\mathbf{6}$ and $\mathbf{7}$ are formed without d.e. Unfortunately, after crystallizations from hot ethanol, the diastereomeric enrichment did not exceed 12 and $27 \%$, for complexes $\mathbf{6}^{\mathbf{a}, \mathbf{b}}$ and $\mathbf{7}^{\mathbf{a}, \mathbf{b}}$, respectively, see scheme 5.

\section{De-coordination of optically pure ligand $\mathrm{L}^{1}$ and determination of its configuration}

According to the literature ${ }^{23,26}$, the enantiomerically enriched phosphine ligand can be released from the cyclopalladated complex by addition of one equivalent of chelating bis(diphenylphosphino)ethane (dppe) ligand and easily isolated by extraction with flash chromatography. Although the ligand can then be coordinated to any transition metal, the orthopalladium complex can not be recovered. However, in few cases, the latter palladium resolving agent has been recycled, for example, by a ligand transmetallation process based on the formation of stronger metal-phosphorus bonds like Pt-P vs Pd-P. ${ }^{23}$ Application of this procedure to complex $2^{\text {a }}$, Scheme 6 , was relatively straightforward (see experimental section).

$<$ Insert Scheme 6>

The optically purity of the free ligand $\mathbf{L}^{1}$ should be at $98 \%$ e.e., the same as the starting complex 2a, because decoordination process does not modify the absolute configuration of the carbon stereogenic centre. In order to determine the absolute configuration, two crystallizations were attempted in a $\mathrm{CH}_{2} \mathrm{Cl}_{2}$ /pentane mixture and in hot ethanol. Unfortunately, no crystals suitable for an X-ray structure analysis were obtained. Consequently, a related palladium complex $\mathbf{8}^{\mathbf{a}}$ was prepared from the optically pure ligand $\mathbf{L}^{\mathbf{1}}$ and $\mathrm{PdCl}_{2}(\mathrm{COD})$, following the same procedure described for the preparation of the racemic mixture of complex $\left[\operatorname{PdCl}_{2}\left\{(R / S) \mathrm{Ph}_{2} \mathrm{P}-\right.\right.$ $\left.\left.\mathrm{CH}_{2} \mathrm{CH}(\mathrm{Ph}) \mathrm{NHPh}-\kappa^{2}-P, N\right\}\right]^{10}$, see Scheme 7.

$<$ Insert Scheme 7> 


\section{$\mathrm{X}$-ray Structure Analysis of complex $\left[\left\{\mathrm{PdCl}_{2}\left\{(R)-\mathrm{Ph}_{2} \mathrm{PCH}_{2} \mathrm{CH}(\mathrm{Ph}) \mathrm{NHPh}-\mathrm{P}, \mathrm{N}\right\}\right] 8^{\mathrm{a}}\right.$}

The asymmetric unit contains two independent molecules linked by two intermolecular hydrogen interactions $\mathrm{NH} \cdots \mathrm{Cl}$ and four $\mathrm{CH}_{2} \mathrm{Cl}_{2}$ solvate molecules. The two conformations differ only by the orientation of the P-phenyl groups. The structure shows that the ligand is $\kappa^{2}-\mathrm{P}, \mathrm{N}$ coordinated in a square planar coordination geometry for the palladium center (see Figure 3). Crystal data and structure refinement parameters are given in Table 1. The selected bond lengths and angles (see Table 3) of this complex are comparable to these reported for two other $\left[\mathrm{PdCl}_{2}(\mathrm{P}, \mathrm{N})\right]$ complexes with $\mathrm{P}, \mathrm{N}=\mathrm{Ph}_{2} \mathrm{PCH}_{2} \mathrm{CH}(\mathrm{Ph}) \mathrm{NHPh}$ and $\mathrm{Ph}_{2} \mathrm{PCH}_{2} \mathrm{CH}\left(\left(\mathrm{CH}_{2}\right)_{2,3} \mathrm{SMe}\right)-$ $\mathrm{NMe}_{2}{ }^{10,32}$ Specifically, the $\mathrm{Pd}-\mathrm{P}, \mathrm{Pd}-\mathrm{N}, \mathrm{Pd}-\mathrm{Cl}(1)$ and $\mathrm{Pd}-\mathrm{Cl}(2)$ distances are very close to those reported in above mentioned complexes. The $\mathrm{Pd}-\mathrm{Cl}(2)$ bond length trans to the $\mathrm{P}$ atom $(2.396(2) \AA)$ is longer than that trans to the $\mathrm{N}$ atom $(\mathrm{Pd}-\mathrm{Cl}(1)=(2.293(2) \AA)$ owing to the stronger trans influence of the $\mathrm{P}$ with respect to the $\mathrm{N}$ donor group. In contrast to the $\left[\mathrm{PdCl}_{2}((R / S)\right.$ $\left.\left.\mathrm{Ph}_{2} \mathrm{PCH}_{2} \mathrm{CH}(\mathrm{Ph}) \mathrm{NHPh}-\kappa^{2}-P, N\right)\right]$ racemate, ${ }^{10}$ optically pure $\mathbf{8}^{\mathbf{a}}$ crystallizes in a non centrosymmetric space group $\left(\mathrm{P} 2_{1}\right)$ because of the presence of only one enantiomer of ligand $\mathbf{L}^{\mathbf{1}}$. The asymmetric $\mathrm{C}_{1}$ carbon atom is found in the rectus configuration (see Figure 3 ). This solid state characterization is also useful as a reference for future separations of diastereomeric palladacycle complexes, because of the absolute chemical shift assignment in the ${ }^{31} \mathrm{P}$ and ${ }^{1} \mathrm{H}$ NMR spectra of compound 2 (for instance, 40.45 and $40.67 \mathrm{ppm}$ for the $S, R$ and $S, S$ diastereomers, respectively, in the ${ }^{31} \mathrm{P}$ NMR spectrum).

\section{<Insert Table 3 and Figure 3>}

\section{Conclusion}

Resolution of the racemic chiral $\beta$-aminophosphines $\mathbf{L}^{\mathbf{1}}$ and $\mathbf{L}^{\mathbf{2}}$ was sought by use of different cyclopalladated complexes as chiral agents. The resulting complexes afford diastereomeric adducts in a one to one ratio and the d.e. does not change significantly after crystallizations from chlorinated solvents. However, a higher d.e. was achieved by successive crystallizations from ethanol in the case of a chloro palladium complex containing the $\mathrm{Ph}_{2} \mathrm{PCH}_{2} \mathrm{CH}(\mathrm{Ph}) \mathrm{NH}(\mathrm{Ph})$ ligand. The $\mathrm{X}$-ray structure analysis has pointed out hydrogen interactions between the P,N ligand amine function and the chloride ion of each diastereomer. These $\mathrm{N}-\mathrm{H}$...C $\mathrm{Cl}$ intermolecular interactions are responsible for the formation and stabilization of the diastereomeric adducts. The use of oxygenated solvents cancels such hydrogen interactions by their stronger donor character and makes the diastereomers 
separation possible, allowing to isolate the optically pure amino-phosphine $(R)-\mathbf{L}^{\mathbf{1}}$. Despite the gram scale availability of the racemic ligand, the enantiomerically pure aminophosphine has been obtained with a low yield, which remains yet similar to those of reported enantioselective syntheses. However, better yields and/or the second enantiomer could be obtained in principle by use of other palladacycle chiral agents. The enantiomerically enriched $(R)-\mathbf{L}^{\mathbf{1}}$ aminophosphine will now be tested in a variety of enantioselective catalyses such as asymmetric rhodium hydroformylation, palladium allylic alkylation or ruthenium double bond hydrogenation.

\section{Acknowledgments}

We are grateful to the Ministère de la Recherche et de la Technologie for support and for a PhD fellowship (to J.-M. C.) and the Centre National de Recherche Scientifique (CNRS) for financial support of this work.

\section{Experimental Section}

All manipulations were carried out under purified argon using standard Schlenk techniques. All solvents were dried and deoxygenated prior to use by standard methods. Standard pressure NMR measurements $\left({ }^{1} \mathrm{H},{ }^{13} \mathrm{C}\left\{{ }^{1} \mathrm{H}\right\}\right.$ and $\left.{ }^{31} \mathrm{P}\left\{{ }^{1} \mathrm{H}\right\}\right)$ were carried out with a Bruker DRX300 spectrometer in $\mathrm{CDCl}_{3}$ at room temperature. The peak positions are reported with positive shifts in ppm downfield of TMS as calculated from the residual solvent peaks $\left({ }^{1} \mathrm{H}\right.$ and $\left.{ }^{13} \mathrm{C}\left\{{ }^{1} \mathrm{H}\right\}\right)$ or downfield of external $85 \% \mathrm{H}_{3} \mathrm{PO}_{4}\left({ }^{31} \mathrm{P}\right)$. NMR data of diastereomers $\mathbf{a}$ and $\mathbf{b}$ of complexes $\mathbf{2 , 3 , 5 , 6}$ and $\mathbf{7}$ are distinguished, respectively, by the absence and the presence of a prime index superscript for the nuclei labelled in bold italic character. All IR spectra were recorded in $\mathrm{CH}_{2} \mathrm{Cl}_{2}$ solution with a Bruker IFS 66V spectrophotometer with $\mathrm{KBr}$ optics and the absorption vibration bands are given in $\mathrm{cm}^{-1}$. Elemental analyses were carried out by the analytical service of the L.S.E.O. with a Fisons Instruments EA1108 analyzer. The commercial compounds $\mathrm{Ph}_{2} \mathrm{PCH}_{2} \mathrm{CH}_{2} \mathrm{PPh}_{2}, \quad(S)-1$ phenylethylamine (98\% e.e.), $\left[\mathrm{Pd}(\mathrm{OAc})_{2}\right]$, and $\left[\mathrm{PdCl}_{2}(\mathrm{COD})\right]$, were used as received. The preparation of ligands $\mathrm{Ph}_{2} \mathrm{PCH}_{2} \mathrm{CH}(\mathrm{Ph}) \mathrm{NHAr} \mathbf{L}^{\mathbf{1}}\left(\mathrm{Ar}=\right.$ Phenyl) and $\mathbf{L}^{\mathbf{2}}(\mathrm{Ar}=2,6$ diisopropylphenyl) was previously described. ${ }^{10,17}$ The cyclopalladated compounds $(S)-\mathbf{4}$ was prepared according to literature. ${ }^{23}$

\section{Synthesis of $\left[\left\{\mathrm{Pd}(\mu-\mathrm{Cl})\left(\mathrm{C}_{6} \mathrm{H}_{4} \mathrm{CHMeNH}_{2}-\kappa^{2}-C, N\right)\right\}_{2}\right](S)-1$}


The dinuclear complex has been prepared according to literature ${ }^{25}$ but its preparation has been improved and its purification step has been optimised by the following procedure. To a mixture of $\mathrm{Pd}(\mathrm{OAc})_{2}(4.17 \mathrm{~g}, 18.6 \mathrm{mmol})$ and $(S)$-1-phenylethylamine $(2.4 \mathrm{ml}, 18.5 \mathrm{mmol})$ was added $75 \mathrm{ml}$ of toluene, instead of benzene as previously described ${ }^{25}$. The mixture was stirred and heated at $50^{\circ} \mathrm{C}$ overnight. The green solution was filtered over Celite in order to eliminate the small amount of zerovalent palladium. A solution of $\mathrm{NaCl}(2 \mathrm{~g})$ in $50 \mathrm{ml}$ of acetone was introduced and the resulting suspension was stirred overnight. A filtration over Celite led to an orange solution which was then evaporated, leading to a yellow solid. Instead of purifying the compound by extraction with hexane as described ${ }^{25}$, it was purified by chromatography using a $\mathrm{CHCl}_{3} / \mathrm{MeOH}$ mixture in a $100 / 2$ ratio. Orange, yellow and brown fractions were obtained and only the orange and yellow fractions were consistent to the expected product by proton NMR. Solvent evaporation of the two last fractions led to the air stable yellow compound $(S)-\mathbf{1}(1.46 \mathrm{~g}, 30 \%)$.

\section{Synthesis of $\mathrm{PdCl}\left[(S)-\mathrm{C}_{6} \mathrm{H}_{4} \mathrm{CH}(\mathrm{Me}) \mathrm{NH}_{2}-\kappa^{2}-C, N\right]\left[\mathrm{Ph}_{2} \mathrm{PCH}_{2} \mathrm{CH}(\mathrm{Ph}) \mathrm{NHPh}-\kappa^{1}-P\right],\left(2^{\mathrm{a}, \mathrm{b}}\right)$}

The chiral palladium dimer $(S)-\mathbf{1}\left(1.29 \mathrm{~g}, 2.5 \mathrm{mmol}\right.$.) and the ligand $\mathbf{L}^{\mathbf{1}}$ (1.89 $\mathrm{g}, 4.9 \mathrm{mmol}$.) were dissolved in $10 \mathrm{ml}$ of $\mathrm{CH}_{2} \mathrm{Cl}_{2}$. The solution was stirred for $1 \mathrm{~h}$ and the solvent was then evaporated. The resulting residue was washed three times with $10 \mathrm{ml}$ of pentane and dried in vacuo (1.43 $\mathrm{g}, 45$ $\%$ ). The product was found to contain the two diastereomers $\mathbf{2}^{\mathbf{a}}$ and $\mathbf{2}^{\mathbf{b}}$ in a $1: 1$ ratio. After three successive crystallizations in hot ethanol, the diastereomer $\mathbf{2}^{\mathbf{a}}$ was isolated as white crystals $(0.369$ g, $12 \%$ ) with $98 \%$ d.e. This purification procedure was repeated three times from different charges of crude product and in all cases the d.e. was at least 98\%. NMR data of the isolated diastereomer 2 $^{\mathrm{a}}$ : ${ }^{1} \mathrm{H}$ : $\delta 1.59\left(\mathrm{~d}, 3 \mathrm{H},{ }^{3} \mathrm{~J}_{\mathrm{HH}}=6.7 \mathrm{~Hz}, \mathrm{CH}-\mathrm{CH}_{3}\right), 2.46$ (s, br, $1 \mathrm{H}$, exchange with $\left.\mathrm{D}_{2} \mathrm{O}, \mathrm{CH}\left(\mathrm{CH}_{3}\right)-\mathrm{NH}\right)$, $2.82\left(\mathrm{dt}, 1 \mathrm{H},{ }^{3} J_{\mathrm{HH}}=2.8 \mathrm{~Hz},{ }^{2} J_{\mathrm{HP}}={ }^{2} J_{\mathrm{HH}}=14.3 \mathrm{~Hz}, \mathrm{PCH}\right), 3.50(\mathrm{~m}, 1 \mathrm{H}, \mathrm{PCH}), 3.97(\mathrm{~m}, 1 \mathrm{H}, \mathrm{NCH}), 4.18$ (m, 1H, $\left.\mathbf{C H}-\mathrm{CH}_{3}\right), 5.19$ (s, br, 1H, exchange with $\left.\mathrm{D}_{2} \mathrm{O}, \mathrm{CH}\left(\mathrm{CH}_{3}\right)-\mathrm{NH}\right), 6.17$ (s, br, 1H, exchange with $\left.\mathrm{D}_{2} \mathrm{O}, \mathrm{CH}\left(\mathrm{CH}_{3}\right)-\mathrm{NH}\right) 6.51-8.21\left(\mathrm{~m}, 24 \mathrm{H}, \boldsymbol{H}_{\text {arom }}\right), 9.05\left(\mathrm{~d},{ }^{3} \mathrm{~J}_{\mathrm{HH}}=11.0 \mathrm{~Hz}\right.$, exchange with $\mathrm{D}_{2} \mathrm{O}$, $\mathrm{Ch}(\mathrm{Ph})-\mathrm{NH}) .{ }^{13} \mathrm{C}\left\{{ }^{1} \mathrm{H}\right\}: \delta 25.8\left(\mathrm{CH}-\mathrm{CH}_{3}\right), 40.3\left(\mathrm{~d}, 1 \mathrm{C},{ }^{2} \boldsymbol{J}_{\mathrm{CP}}=28 \mathrm{~Hz}, \mathrm{PCH}_{2}\right), 57.6\left(\boldsymbol{C H}-\mathrm{CH}_{3}\right), 66.5$ $(\mathrm{NCH}), 122.4-159.8\left(\mathrm{~m}, 30 \mathrm{C}, \boldsymbol{C}_{\text {arom}}\right) .{ }^{31} \mathrm{P}\left\{{ }^{1} \mathrm{H}\right\}: \delta 40.45(\mathrm{~s}, \boldsymbol{P})$. NMR data of the non-isolated diastereomer $2^{\text {b: }}{ }^{1} \mathrm{H}$ : $\delta 1.25\left(\mathrm{~d}, 3 \mathrm{H},{ }^{3} \mathrm{~J}_{\mathrm{HH}}=6.7 \mathrm{~Hz}, \mathrm{CH}-\mathrm{CH}_{3}{ }^{\prime}\right), 1.82$ (s, br, 1H, exchange with $\mathrm{D}_{2} \mathrm{O}$, $\left.\mathrm{CH}\left(\mathrm{CH}_{3}\right)-\mathrm{N} \boldsymbol{H}^{\prime}\right), 2.86\left(\mathrm{dt}, 1 \mathrm{H},{ }^{3} J_{\mathrm{HH}}=2.6 \mathrm{~Hz},{ }^{2} J_{\mathrm{HP}}={ }^{2} J_{\mathrm{HH}}=14.3 \mathrm{~Hz}, \mathrm{PC} \boldsymbol{H}^{\prime}\right), 3.50$ (m, 1H, PCH'), 3.97 (m, 1H, $\mathrm{NCH}$ '), 4.30 (m, 1H, CH'-CH $), 4.58$ (s, br, 1H, exchange with $\left.\mathrm{D}_{2} \mathrm{O}, \mathrm{CH}\left(\mathrm{CH}_{3}\right)-\mathrm{NH}^{\prime}\right), 6.51$ $8.21\left(\mathrm{~m}, 24 \mathrm{H}, \boldsymbol{H}^{\prime}\right.$ arom $), 9.15\left(\mathrm{~d},{ }^{3} \boldsymbol{J}_{\mathrm{HH}}=10.8 \mathrm{~Hz}\right.$, exchange with $\left.\mathrm{D}_{2} \mathrm{O}, \mathrm{Ch}(\mathrm{Ph})-\mathrm{N} \boldsymbol{H}^{\prime}\right) .{ }^{13} \mathrm{C}\left\{{ }^{1} \mathrm{H}\right\}: \delta 25.7$ $\left(\mathrm{CH}-C^{\prime} \mathrm{H}_{3}\right), 40.3\left(\mathrm{~d}, 1 \mathrm{C},{ }^{2} J_{\mathrm{CP}}=28 \mathrm{~Hz}, \mathrm{PC}{ }^{\prime} \mathrm{H}_{2}\right), 56.8\left(\boldsymbol{C}^{\prime} \mathrm{H}^{-} \mathrm{CH}_{3}\right), 66.4\left(\mathrm{NC}{ }^{\prime} \mathrm{H}\right), 122.4-159.8(\mathrm{~m}, 30 \mathrm{C}$, $\boldsymbol{C}_{\text {arom). }}{ }^{31} \mathrm{P}\left\{{ }^{1} \mathrm{H}\right\}: \delta 40.67$ (s, $\boldsymbol{P}^{\prime}$ ). Anal. calcd. for $\mathrm{C}_{34} \mathrm{H}_{34} \mathrm{~N}_{2} \mathrm{PClPd}(643.5): \mathrm{C}, 63.46 ; \mathrm{H}, 5.33 ; \mathrm{N}$, $4.35 \%$. Found; C, 63.15; H, 5.46; N, 4.49\%. 
Synthesis of $\operatorname{PdCl}\left[(S)-\mathrm{C}_{6} \mathrm{H}_{4} \mathrm{CH}(\mathrm{Me}) \mathrm{NH}_{2}-\kappa^{2}-C, N\right]\left[\mathrm{Ph}_{2} \mathrm{PCH}_{2} \mathrm{CH}(\mathrm{Ph}) \mathrm{NH}\left(2,6-\mathrm{C}_{6} \mathrm{H}_{3}{ }^{\mathrm{i}} \mathrm{Pr}_{2}\right)-\kappa^{1}-P\right]$, $\left(3^{\mathrm{a}, \mathrm{b}}\right)$

A mixture of $(S)$-1 palladium dimer $(1.18 \mathrm{~g}, 2.25 \mathrm{mmol})$ and ligand $\mathbf{L}^{2}(2.11 \mathrm{~g}, 4.53 \mathrm{mmol})$ was dissolved in $30 \mathrm{ml}$ of THF. After stirring for $1.5 \mathrm{~h}$, the solvent was removed and the orange residue was purified by flash chromatography over silica gel by use of a $\mathrm{CHCl}_{3} /$ isopropanol mixture in a 20/1 ratio. After solvent evaporation, the diastereomers were found in 1:1 ratio and isolated as a yellow air stable solid, which was dried in vacuo $(1.18 \mathrm{~g}, 36 \%)$. In contrast to complexes $\mathbf{2}^{\mathbf{a}, \mathbf{b}}$, the successive crystallizations in hot ethanol did not affected the diastereomeric excess of $\mathbf{3}^{\mathbf{a}, \mathbf{b}}$. NMR data of diastereomer $3^{\mathrm{a}}:{ }^{1} \mathrm{H}: \delta 0.67\left(\mathrm{~s}, \mathrm{br}, 6 \mathrm{H}, \mathrm{CH}-\left(\mathrm{CH}_{3}\right)_{2}\right), 0.88\left(\mathrm{~s}, \mathrm{br}, 6 \mathrm{H}, \mathrm{CH}-\left(\mathrm{CH}_{3}\right)_{2}\right), 1.50(\mathrm{~d}, 3 \mathrm{H}$, $\left.{ }^{3} J_{\mathrm{HH}}=6.6 \mathrm{~Hz}, \mathrm{NCH}-\mathrm{CH}_{3}\right), 2.32\left(\mathrm{~s}\right.$, br, $1 \mathrm{H}$, exchange with $\left.\mathrm{D}_{2} \mathrm{O}, \mathrm{CH}\left(\mathrm{CH}_{3}\right)-\mathrm{NH}{ }^{a}\right), 2.94(\mathrm{dt}, 1 \mathrm{H}$, $\left.{ }^{3} J_{\mathrm{HH}}=2.8 \mathrm{~Hz},{ }^{2} J_{\mathrm{HP}}={ }^{2} J_{\mathrm{HH}}=14.7 \mathrm{~Hz}, \mathrm{PC} \boldsymbol{H}^{a}\right), 3.72\left(\mathrm{~m}, 2 \mathrm{H}, \mathrm{CH}-\left(\mathrm{CH}_{3}\right)_{2}\right), 3.89(\mathrm{~m}, 1 \mathrm{H}, \mathrm{NCH}), 4.08$ (q, $\left.1 \mathrm{H},{ }^{3} \boldsymbol{J}_{\mathrm{HH}}=6.3 \mathrm{~Hz}, \mathrm{CH}-\mathrm{CH}_{3}\right), 4.35\left(\mathrm{~m}, 1 \mathrm{H}\right.$, exchange with $\left.\mathrm{D}_{2} \mathrm{O}, \mathrm{CH}\left(\mathrm{CH}_{3}\right)-\mathrm{N} \boldsymbol{H}^{b}\right), 4.44(\mathrm{~m}, 1 \mathrm{H}$, PCH $\left.\boldsymbol{H}^{b}\right), 6.51-8.21\left(\mathrm{~m}, 23 \mathrm{H}, \boldsymbol{H}_{\text {arom }}\right.$ and $\left.\mathrm{CH}(\mathrm{Ph})-\mathrm{NH}\right) .{ }^{13} \mathrm{C}\left\{{ }^{1} \mathrm{H}\right\}: \delta 24.4,25,1,25.7$ and 28.6, (s, br, 4C, $\left.\mathrm{CH}\left(\boldsymbol{C H}_{3}\right)_{2}\right), 38.4\left(\mathrm{~d},{ }^{2} \boldsymbol{J}_{\mathrm{CP}}=28 \mathrm{~Hz}, \mathrm{P} \boldsymbol{C} \mathrm{H}_{2}\right), 57.7\left(\boldsymbol{C H}-\mathrm{CH}_{3}\right), 65.6\left(\mathrm{~d},{ }^{3} \boldsymbol{J}_{\mathrm{CP}}=4 \mathrm{~Hz}, \mathrm{NCH}\right), 123.8-159.4$

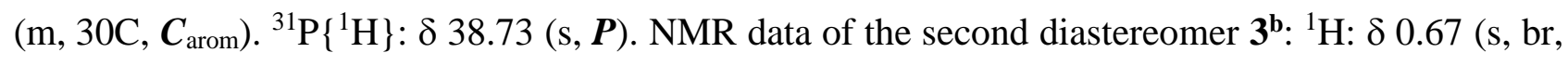
$\left.6 \mathrm{H}, \mathrm{CH}-\left(\mathrm{CH}_{3}{ }_{3}\right)_{2}\right), 0.88$ (s, br, 6H, CH-(CH' $\left.\left.{ }_{3}\right)_{2}\right), 1.17\left(\mathrm{~d}, 3 \mathrm{H},{ }^{3} \mathrm{~J}_{\mathrm{HH}}=6.8 \mathrm{~Hz}, \mathrm{NCH}-\mathrm{CH}_{3}{ }_{3}\right), 2.32$ (s, br, $1 \mathrm{H}$, exchange with $\left.\mathrm{D}_{2} \mathrm{O}, \mathrm{CH}\left(\mathrm{CH}_{3}\right)-\mathrm{NH}^{a}{ }^{\prime}\right), 2.94\left(\mathrm{dt}, 1 \mathrm{H},{ }^{3} J_{\mathrm{HH}}=2.8 \mathrm{~Hz},{ }^{2} \boldsymbol{J}_{\mathrm{HP}}={ }^{2} J_{\mathrm{HH}}=14.7 \mathrm{~Hz}, \mathrm{PC} \boldsymbol{H}^{\prime}\right)$, $3.72\left(\mathrm{~m}, 1 \mathrm{H}, \mathrm{CH}^{\prime}-\left(\mathrm{CH}_{3}\right)_{2}\right), 3.89$ (m, 1H, $\mathrm{NCH}$ '), 4.08 (q, 1H, $\left.{ }^{3} \boldsymbol{J}_{\mathrm{HH}}=6.3 \mathrm{~Hz}, \mathrm{CH}-\mathrm{CH}_{3}\right), 4.35$ (m, 1H, exchange with $\mathrm{D}_{2} \mathrm{O}, \mathrm{CH}\left(\mathrm{CH}_{3}\right)-\mathrm{NH}^{\boldsymbol{b}}$ '), $4.44\left(\mathrm{~m}, 1 \mathrm{H}, \mathrm{PCH}\right.$ ), 4.52 (q, $1 \mathrm{H},{ }^{3} \mathrm{~J}_{\mathrm{HH}}=6.3 \mathrm{~Hz}, \mathrm{CH}^{\prime}-\mathrm{CH}_{3}$ ), 6.51-8.21 (m, 23H, $\boldsymbol{H}^{\prime}$ arom and $\left.\mathrm{CH}(\mathrm{Ph})-\mathrm{N} \boldsymbol{H}^{\prime}\right) .{ }^{13} \mathrm{C}\left\{{ }^{1} \mathrm{H}\right\}: \delta 24.4,25.1,25.7$ and 28.4 (s, br, 4C, $\left.\boldsymbol{C}^{\prime} \mathrm{H}\left(\mathrm{CH}_{3}\right)_{2}\right), 37.8\left(\mathrm{~d},{ }^{2} \boldsymbol{J}_{\mathrm{CP}}=28 \mathrm{~Hz}, \mathrm{P} \boldsymbol{C}^{\prime} \mathrm{H}_{2}\right), 57.6\left(\boldsymbol{C}^{\prime} \mathrm{H}_{-} \mathrm{CH}_{3}\right), 64.3\left(\mathrm{~d},{ }^{3} \boldsymbol{J}_{\mathrm{CP}}=4 \mathrm{~Hz}, \mathrm{~N} \boldsymbol{C}^{\prime} \mathrm{H}\right), 123.8-159.4$ (m, 30C, $\boldsymbol{C}^{\prime}$ arom). ${ }^{31} \mathrm{P}\left\{{ }^{1} \mathrm{H}\right\}: 38.51$ (s, $\boldsymbol{P}^{\prime}$ ). Anal. calcd. for $\mathrm{C}_{40} \mathrm{H}_{46} \mathrm{~N}_{2} \mathrm{PClPd}$ (727.6): C, 66.02; H, 6.37; N, 3.85\%. Found; 65.67; H, 6.31; N, 3.99\%.

\section{Synthesis of $\mathrm{PdCl}\left[(S)-\mathrm{C}_{12} \mathrm{H}_{6} \mathrm{CH}(\mathrm{Me}) \mathrm{NH}_{2}-\kappa^{2}-C, N\right]\left[\mathrm{Ph}_{2} \mathrm{PCH}_{2} \mathrm{CH}(\mathrm{Ph}) \mathrm{NHPh}-\kappa^{1}-P\right],\left(5^{\mathrm{a}, \mathrm{b}}\right)$}

The compound $\mathbf{5}^{\mathbf{a}, \mathbf{b}}$ has been prepared according to the same procedure described above for $2^{\mathbf{a}, \mathbf{b}}$, starting from the dinuclear palladium complex $(S)-4(0.78 \mathrm{~g}, 1.2 \mathrm{mmol})$ and ligand $\mathbf{L}^{\mathbf{1}}(0.90 \mathrm{~g}, 2.4$ mmol). It has been obtained as a white powder (1.38 g, 85\%) without any diastereomeric excess. Successive crystallizations in hot ethanol did not increased the d.e. NMR data for $\mathbf{5}^{\mathbf{a}}$ and $\mathbf{5}^{\mathbf{b}}:{ }^{1} \mathrm{H}$ : $\delta$ $1.32\left(\mathrm{~d}, 3 \mathrm{H},{ }^{3} \mathrm{~J}_{\mathrm{HH}}=6.3 \mathrm{~Hz}, \mathrm{CH}-\mathrm{CH}_{3}\right), 1.57\left(\mathrm{~s}, \mathrm{br}, 1 \mathrm{H}\right.$, exchange with $\left.\mathrm{D}_{2} \mathrm{O}, \mathrm{CH}\left(\mathrm{CH}_{3}\right)-\mathrm{NH}\right) 1.76(\mathrm{~d}$, $\left.3 \mathrm{H},{ }^{3} \boldsymbol{J}_{\mathrm{HH}}=6.2 \mathrm{~Hz}, \mathrm{CH}-\mathrm{CH}_{3}\right), 2.77\left(\mathrm{~m}, 2 \mathrm{H}, \mathrm{PC} \boldsymbol{H}\right.$ et $\left.\mathrm{CH}\left(\mathrm{CH}_{3}\right)-\mathrm{NH}\right), 2.89\left(\mathrm{dt}, 1 \mathrm{H},{ }^{3} \boldsymbol{J}_{\mathrm{HH}}=2.8 \mathrm{~Hz}\right.$, 
$\left.{ }^{2} J_{\mathrm{HH}}={ }^{2} J_{\mathrm{HP}}=14.2 \mathrm{~Hz}, \mathrm{PCH}\right), 2.96\left(\mathrm{~s}, \mathrm{br}, 2 \mathrm{H}\right.$, exchange with $\left.\mathrm{D}_{2} \mathrm{O}, 2 \mathrm{CH}\left(\mathrm{CH}_{3}\right)-\mathrm{NH}\right), 3.56(\mathrm{dt}, 1 \mathrm{H}$, $\left.{ }^{3} J_{\mathrm{HH}}=3.6 \mathrm{~Hz},{ }^{2} J_{\mathrm{HH}}={ }^{2} J_{\mathrm{HP}}=14.2 \mathrm{~Hz}, \mathrm{PCH}\right), 3.83(\mathrm{~m}, 2 \mathrm{H}, \mathrm{NCH}$ et $\mathrm{PC} \boldsymbol{H}), 4.12\left(\mathrm{ddd}, 1 \mathrm{H},{ }^{3} J_{\mathrm{HH}}=2.7 \mathrm{~Hz}\right.$, $\left.{ }^{3} \boldsymbol{J}_{\mathrm{HH}}=3.6 \mathrm{~Hz},{ }^{2} \boldsymbol{J}_{\mathrm{HP}}=10.4 \mathrm{~Hz}, \mathrm{NCH}\right), 4.97\left(\mathrm{~m}, 2 \mathrm{H}, 2 \mathrm{C} \boldsymbol{H}-\mathrm{CH}_{3}\right), 6.95-8.33\left(\mathrm{~m}, 52 \mathrm{H}, \boldsymbol{H}_{\text {arom}}\right), 10.03(\mathrm{~d}$, $1 \mathrm{H}$, exchange with $\left.\mathrm{D}_{2} \mathrm{O},{ }^{3} \boldsymbol{J}_{\mathrm{HH}}=9.6 \mathrm{~Hz}, \mathrm{NH}\right), 10.07\left(\mathrm{~d}, 1 \mathrm{H}\right.$, exchange with $\left.\mathrm{D}_{2} \mathrm{O},{ }^{3} J_{\mathrm{HH}}=9.7 \mathrm{~Hz}, \mathrm{NH}\right)$. ${ }^{13} \mathrm{C}\left\{{ }^{1} \mathrm{H}\right\}: \delta 25.2\left(\mathrm{CH}-\mathrm{CH}_{3}\right), 25.9\left(\mathrm{CH}-\mathrm{CH}_{3}\right), 42.2\left(\mathrm{~d},{ }^{2} J_{\mathrm{CP}}=28 \mathrm{~Hz}, \mathrm{PC} \mathrm{H}_{2}\right), 42.9\left(\mathrm{~d},{ }^{2} J_{\mathrm{CP}}=29 \mathrm{~Hz}\right.$, $\left.\mathrm{PCH}_{2}\right), 55.1\left(\boldsymbol{C H}-\mathrm{CH}_{3}\right), 56.4\left(\boldsymbol{C H}-\mathrm{CH}_{3}\right), 66.0(\mathrm{NCH}), 67.4(\mathrm{NCH}), 122.7-155.5\left(\mathrm{~m}, 68 \mathrm{C}, \boldsymbol{C}_{\text {arom}}\right)$. ${ }^{31} \mathrm{P}\left\{{ }^{1} \mathrm{H}\right\}: \delta 41.01$ (s, P), 41.37 (s, $\boldsymbol{P}$ '). Anal. calcd. for $\mathrm{C}_{38} \mathrm{H}_{36} \mathrm{~N}_{2} \mathrm{PClPd}(693.5): \mathrm{C}, 65.81 ; \mathrm{H}, 5.23 ; \mathrm{N}$, $4.04 \%$. Found; C, 65.32; H, 5.61; N, 3.79\%.

\section{Synthesis of $\left\{\mathrm{Pd}\left[(S)-\mathrm{C}_{6} \mathrm{H}_{4} \mathrm{CH}(\mathrm{Me}) \mathrm{NH}_{2}-\kappa^{2}-C, N\right]\left[\mathrm{Ph}_{2} \mathrm{PCH}_{2} \mathrm{CH}(\mathrm{Ph}) \mathrm{NHPh}-\kappa^{2}-P, N\right]\right\}^{+} \mathrm{PF}_{6}{ }^{-}\left(6^{\mathrm{a}, \mathrm{b}}\right)$}

To a solution of palladium dimer $(S)-\mathbf{1}(0.75 \mathrm{~g}, 1.4 \mathrm{mmol})$ in $20 \mathrm{ml}$ of $\mathrm{CH}_{2} \mathrm{Cl}_{2}$ was added a solution of ligand $\mathbf{L}^{\mathbf{1}}$ (1.08 g, $\left.2.8 \mathrm{mmol}\right)$ in $10 \mathrm{ml}$ of $\mathrm{CH}_{2} \mathrm{Cl}_{2}$ and the mixture was stirred for $2 \mathrm{~h}$. The solution was then added to a suspension of $\mathrm{NaPF}_{6}(0.66 \mathrm{~g}, 3.9 \mathrm{mmol})$ in $5 \mathrm{ml}$ of $\mathrm{CH}_{2} \mathrm{Cl}_{2}$ and stirred for $4 \mathrm{~h}$. The resulting yellow solution was then filtered over Celite and concentrated until a precipitate appeared. This was washed three times with $30 \mathrm{ml}$ of pentane and dissolved in hot ethanol. After cooling to $-30^{\circ} \mathrm{C}$, complex 6 was obtained as a white microcrystalline product $(1.58 \mathrm{~g}, 75 \%)$, without any d.e. (by integration of ${ }^{1} \mathrm{H}$ NMR spectrum). A low d.e. of $12 \%$ was obtained after two successive crystallizations in hot ethanol. NMR data for both diastereomers $\mathbf{6}^{\mathbf{a}}$ and $\mathbf{6}^{\mathbf{b}}$ : ${ }^{1} \mathrm{H}: \delta 1.18$ $\left(\mathrm{d}, 3 \mathrm{H},{ }^{3} \mathrm{~J}_{\mathrm{HH}}=6.5 \mathrm{~Hz}, \mathrm{CH}-\mathrm{CH}_{3}\right), 1.52\left(\mathrm{~d}, 3 \mathrm{H},{ }^{3} \mathrm{~J}_{\mathrm{HH}}=6.4 \mathrm{~Hz}, \mathrm{CH}-\mathrm{CH}_{3}\right), 1.78$ (s, br, 1H, exchange with $\left.\mathrm{D}_{2} \mathrm{O}, \mathrm{NH}\right), 2.51\left(\mathrm{~s}, \mathrm{br}, 1 \mathrm{H}\right.$, exchange with $\left.\mathrm{D}_{2} \mathrm{O}, \mathrm{N} \boldsymbol{H}\right), 2.90\left(\mathrm{dt}, 2 \mathrm{H}, \boldsymbol{J}_{\mathrm{HH}}=3.2 \mathrm{~Hz},{ }^{2} J_{\mathrm{HP}}={ }^{2} J_{\mathrm{HH}}=14.4 \mathrm{~Hz}\right.$, PCH et PCH'), $3.23\left(\mathrm{dt}, 2 \mathrm{H},{ }^{3} J_{\mathrm{HH}}=3.2 \mathrm{~Hz},{ }^{2} J_{\mathrm{HP}}={ }^{2} J_{\mathrm{HH}}=14.6 \mathrm{~Hz}, \mathrm{PC} \boldsymbol{H}\right.$ et PCH'), $3.56(\mathrm{~s}, \mathrm{br}, 1 \mathrm{H}$, exchange with $\left.\mathrm{D}_{2} \mathrm{O}, \mathrm{N} \boldsymbol{H}\right), 3.90$ (m, 2H, $\mathrm{NCH}$ et $\left.\mathrm{NC} \boldsymbol{H}^{\prime}\right), 4.25$ (m, 2H, $\mathbf{C} \boldsymbol{H}-\mathrm{CH}_{3}$ et $\left.\mathrm{CH}^{\prime}-\mathrm{CH}_{3}\right), 4.49$ (s, br, $1 \mathrm{H}$, exchange with $\left.\mathrm{D}_{2} \mathrm{O}, \mathrm{NH}\right), 6.26\left(\mathrm{~m}, 2 \mathrm{H}\right.$, exchange with $\left.\mathrm{D}_{2} \mathrm{O}, \mathrm{NH}\right), 6.48-8.12(\mathrm{~m}, 48 \mathrm{H}$, $\boldsymbol{H}_{\text {arom }}$ and $\boldsymbol{H}^{\prime}$ arom $) .{ }^{13} \mathrm{C}\left\{{ }^{1} \mathrm{H}\right\}: \delta 25.5\left(\mathrm{CH}-\boldsymbol{C}^{\prime} \mathrm{H}_{3}\right), 26.3\left(\mathrm{CH}-\boldsymbol{C H}_{3}\right), 40.0\left(\mathrm{~d}, 2 \mathrm{C},{ }^{2} \boldsymbol{J}_{\mathrm{CP}}=28 \mathrm{~Hz}, \mathrm{P} \boldsymbol{C} \mathrm{H}_{2}\right.$ and $\left.\mathrm{P}^{\prime}{ }^{\prime} \mathrm{H}_{2}\right), 57.3\left(\boldsymbol{C H}-\mathrm{CH}_{3}\right), 57.8\left(\boldsymbol{C}^{\prime} \mathrm{H}-\mathrm{CH}_{3}\right), 66.9\left(\mathrm{~d}, 2 \mathrm{C},{ }^{3} \boldsymbol{J}_{\mathrm{CP}}=6 \mathrm{~Hz}, \mathrm{~N} \boldsymbol{C H}\right.$ et $\left.\mathrm{N} \boldsymbol{C}{ }^{\prime} \mathrm{H}\right), 122.4-157.1(\mathrm{~m}$, 60C, $\boldsymbol{C}_{\text {arom }}$ and $\boldsymbol{C}_{\text {arom }}{ }{ }^{31} \mathrm{P}\left\{{ }^{1} \mathrm{H}\right\}: \delta 41.32(\mathrm{~s}, \boldsymbol{P}), 41.23$ (s, br, $\left.\boldsymbol{P}^{\prime}\right),-143.2\left(\mathrm{~h},{ }^{1} J_{\mathrm{PF}}=715 \mathrm{~Hz}, \mathrm{PF}_{6}{ }^{-}\right)$. Anal. calcd. for $\mathrm{C}_{34} \mathrm{H}_{34} \mathrm{~N}_{2} \mathrm{~F}_{6} \mathrm{P}_{2} \mathrm{Pd}$ (753.0): C, 54.23\%; H, 4.55; N, 3.72\%. Found: C, 54.73; H, 4.55; $\mathrm{N}, 3.87 \%$.

\section{Synthesis of $\quad\left\{\mathrm{Pd}\left[(S)-\mathrm{C}_{6} \mathrm{H}_{4} \mathrm{CH}(\mathrm{Me}) \mathrm{NH}_{2}-\kappa^{2}-C, N\right]\left[\mathrm{Ph}_{2} \mathrm{PCH}_{2} \mathrm{CH}(\mathrm{Ph}) \mathrm{NH}\left(2,6-\mathrm{C}_{6} \mathrm{H}_{3} \mathrm{Pr}_{2}\right)-\kappa^{2}-\right.\right.$ $P, N]\}^{+} \mathbf{P F}^{-}\left(7^{\mathrm{a}, \mathrm{b}}\right)$}

Complexes $\mathbf{7}^{\mathbf{a}, \mathbf{b}}$ were prepared by the same procedure described above for complexes $\mathbf{6}$, starting from palladium dimmer $(S)-\mathbf{1}(0.58 \mathrm{~g}, 1.1 \mathrm{mmol})$, ligand $\mathbf{L}^{2}(1.03 \mathrm{~g}, 2.2 \mathrm{mmol})$, and NaPF $6(0.47 \mathrm{~g}$, $2.8 \mathrm{mmol})$. They were obtained as white needles $(1.31 \mathrm{~g}, 82 \%)$, without any d.e. A distereomeric 
excess of $27 \%$ was obtained after two successive crystallizations in hot ethanol. NMR data for both diastereomers $\mathbf{7}^{\mathbf{a}, \mathbf{b}} .{ }^{1} \mathrm{H}: \delta 0.08\left(\mathrm{~d}, 3 \mathrm{H},{ }^{3} \boldsymbol{J}_{\mathrm{HH}}=6.4 \mathrm{~Hz}, \mathrm{CH}-\left(\mathrm{CH}_{3}\right)_{2}\right), 0.17\left(\mathrm{~d}, 3 \mathrm{H},{ }^{3} \boldsymbol{J}_{\mathrm{HH}}=6.4 \mathrm{~Hz}, \mathrm{CH}-\right.$ $\left.\left(\mathrm{CH}_{3}\right)_{2}\right), 0.59\left(\mathrm{~d}, 3 \mathrm{H},{ }^{3} \mathrm{~J}_{\mathrm{HH}}=6.3 \mathrm{~Hz}, \mathrm{CH}-\left(\mathrm{CH}_{3}\right)_{2}\right), 0.61\left(\mathrm{~d}, 3 \mathrm{H},{ }^{3} \mathrm{~J}_{\mathrm{HH}}=6.3 \mathrm{~Hz}, \mathrm{CH}-\left(\mathrm{CH}_{3}\right)_{2}\right), 1.07(\mathrm{~d}, 3 \mathrm{H}$, $\left.{ }^{3} J_{\mathrm{HH}}=6.3 \mathrm{~Hz}, \mathrm{CH}-\left(\mathrm{CH}_{3}\right)_{2}\right), 1.08\left(\mathrm{~d}, 3 \mathrm{H},{ }^{3} J_{\mathrm{HH}}=6.2 \mathrm{~Hz}, \mathrm{CH}-\left(\mathrm{CH}_{3}\right)_{2}\right), 1.15\left(\mathrm{~d}, 3 \mathrm{H},{ }^{3} J_{\mathrm{HH}}=6.9 \mathrm{~Hz}, \mathrm{CH}-\right.$ $\left.\mathrm{CH}_{3}\right), 1.19\left(\mathrm{~d}, 3 \mathrm{H},{ }^{3} \mathrm{~J}_{\mathrm{HH}}=6.8 \mathrm{~Hz}, \mathrm{CH}-\left(\mathrm{CH}_{3}\right)_{2}\right), 1.20\left(\mathrm{~d}, 3 \mathrm{H},{ }^{3} \mathrm{~J}_{\mathrm{HH}}=6.8 \mathrm{~Hz}, \mathrm{CH}-\left(\mathrm{CH}_{3}\right)_{2}\right), 1.48(\mathrm{~d}, 3 \mathrm{H}$, $\left.{ }^{3} J_{\mathrm{HH}}=6.8 \mathrm{~Hz}, \mathrm{CH}-\mathrm{CH}_{3}\right), 1.78\left(\mathrm{~m}\right.$, br, $1 \mathrm{H}$, exchange with $\left.\mathrm{D}_{2} \mathrm{O}, \mathrm{NH}\right), 2.58(\mathrm{~m}, 1 \mathrm{H}$, exchange with $\left.\mathrm{D}_{2} \mathrm{O}, \mathrm{NH}\right), 2.75\left(\mathrm{~h}, 1 \mathrm{H},{ }^{3} \mathrm{~J}_{\mathrm{HH}}=6.8 \mathrm{~Hz}, \mathrm{CH}-\left(\mathrm{CH}_{3}\right)_{2}\right), 2.77\left(\mathrm{~h}, 1 \mathrm{H},{ }^{3} \boldsymbol{J}_{\mathrm{HH}}=6.6 \mathrm{~Hz}, \mathrm{CH}-\left(\mathrm{CH}_{3}\right)_{2}\right), 2.94$ (dt, $\left.1 \mathrm{H},{ }^{3} J_{\mathrm{HH}}=3.0 \mathrm{~Hz},{ }^{2} J_{\mathrm{HH}}={ }^{2} J_{\mathrm{HP}}=15.0 \mathrm{~Hz}, \mathrm{PC} \boldsymbol{H}\right), 2.95\left(\mathrm{dt}, 1 \mathrm{H},{ }^{3} J_{\mathrm{HH}}=3.2 \mathrm{~Hz},{ }^{2} J_{\mathrm{HH}}={ }^{2} J_{\mathrm{HP}}=15.0 \mathrm{~Hz}, \mathrm{PC} \boldsymbol{H}\right)$, $3.08\left(\mathrm{~m}, 1 \mathrm{H}\right.$, exchange with $\left.\mathrm{D}_{2} \mathrm{O}, \mathrm{NH}\right), 3.52\left(\mathrm{dt}, 1 \mathrm{H},{ }^{3} J_{\mathrm{HH}}=4.7 \mathrm{~Hz},{ }^{2} \boldsymbol{J}_{\mathrm{HH}}={ }^{2} J_{\mathrm{HP}}=14.6 \mathrm{~Hz}, \mathrm{PCH}\right), 3.61$ $\left(\mathrm{dt}, 1 \mathrm{H},{ }^{3} J_{\mathrm{HH}}=4.6 \mathrm{~Hz},{ }^{2} J_{\mathrm{HH}}={ }^{2} J_{\mathrm{HP}}=14.5 \mathrm{~Hz}, \mathrm{PCH}\right), 3.73\left(\mathrm{~h}, 1 \mathrm{H},{ }^{3} J_{\mathrm{HH}}=6.6 \mathrm{~Hz}, \mathrm{CH}-\left(\mathrm{CH}_{3}\right)_{2}\right), 3.86(\mathrm{~m}$, $\left.2 \mathrm{H}, \mathrm{CH}-\mathrm{CH}_{3} \& \mathrm{NCH}\right), 3.95(\mathrm{~m}, 1 \mathrm{H}, \mathrm{NCH}), 4.12\left(\mathrm{~m}, 2 \mathrm{H}, \mathrm{CH}-\mathrm{CH}_{3}\right.$ and $\left.\mathrm{NH}\right), 4.43(\mathrm{~m}, 1 \mathrm{H}, \mathrm{CH}-$ $\left.\left(\mathrm{CH}_{3}\right)_{2}\right) 5.94\left(\mathrm{~d}, 1 \mathrm{H}\right.$, exchange with $\left.\mathrm{D}_{2} \mathrm{O},{ }^{3} \mathrm{~J}_{\mathrm{HH}}=10.9 \mathrm{~Hz}, \mathrm{NH}\right), 5.96\left(\mathrm{~d}, 1 \mathrm{H}\right.$, exchange with $\mathrm{D}_{2} \mathrm{O}$, $\left.{ }^{3} \boldsymbol{J}_{\mathrm{HH}}=10.9 \mathrm{~Hz}, \mathrm{NH}\right), 6.48-8.06\left(\mathrm{~m}, 48 \mathrm{H}, \boldsymbol{H}_{\text {arom }}\right) .{ }^{13} \mathrm{C}\left\{{ }^{1} \mathrm{H}\right\}: \delta 23.2\left(1 \mathrm{C}, \mathrm{CH}\left(\boldsymbol{C H}_{3}\right)_{2}\right), 23.7(1 \mathrm{C}$, $\left.\mathrm{CH}\left(\mathrm{CH}_{3}\right)_{2}\right), 24.1\left(1 \mathrm{C}, \mathrm{CH}\left(\mathrm{CH}_{3}\right)_{2}\right), 24.4\left(1 \mathrm{C}, \mathrm{CH}\left(\mathrm{CH}_{3}\right)_{2}\right), 25.6\left(1 \mathrm{C}, \mathrm{CH}\left(\boldsymbol{C H}_{3}\right)_{2}\right), 25.8(1 \mathrm{C}$, $\left.\mathrm{CH}\left(\boldsymbol{C H}_{3}\right)_{2}\right), 26.3\left(1 \mathrm{C}, \mathrm{CH}\left(\boldsymbol{C H}_{3}\right)_{2}\right), 26.4\left(1 \mathrm{C}, \mathrm{CH}\left(\boldsymbol{C H}_{3}\right)_{2}\right), 27.5\left(\boldsymbol{C H}\left(\mathrm{CH}_{3}\right)_{2}\right), 27.6\left(\boldsymbol{C H}\left(\mathrm{CH}_{3}\right)_{2}\right), 29.3$ $\left(\boldsymbol{C H}\left(\mathrm{CH}_{3}\right)_{2}\right), 29.4\left(\boldsymbol{C H}\left(\mathrm{CH}_{3}\right)_{2}\right), 37.3\left(\mathrm{~d},{ }^{2} \boldsymbol{J}_{\mathrm{CP}}=29 \mathrm{~Hz}, \mathrm{P} \boldsymbol{C H}\right)_{2}, 37.8\left(\mathrm{~d},{ }^{2} J_{\mathrm{CP}}=16 \mathrm{~Hz}, \mathrm{PC} \mathrm{H}_{2}\right), 57.4(\boldsymbol{C H}-$ $\left.\mathrm{CH}_{3}\right), 58.0\left(\boldsymbol{C H}-\mathrm{CH}_{3}\right), 64.8\left(\mathrm{~d},{ }^{3} J_{\mathrm{CP}}=4 \mathrm{~Hz}, \mathrm{NCH}\right), 65.0\left(\mathrm{~d},{ }^{3} J_{\mathrm{CP}}=4 \mathrm{~Hz}, \mathrm{NCH}\right), 123.4-157.0(\mathrm{~m}, 60 \mathrm{C}$, $\boldsymbol{C}_{\text {arom }) .}{ }^{31} \mathrm{P}\left\{{ }^{1} \mathrm{H}\right\}: \delta 39.4(\mathrm{~s}, 1 \boldsymbol{P}), 39.0$ (s, $\left.1 \boldsymbol{P}^{\prime}\right),-143.4\left(\mathrm{~h}, \mathrm{PF}_{6}{ }^{-}\right)$. Anal. calcd. for $\mathrm{C}_{40} \mathrm{H}_{46} \mathrm{~N}_{2} \mathrm{~F}_{6} \mathrm{PPd}$ (837.1): C, 57.39; H, 5.54; N, 3.35\%. Found: C, 57.07; H, 5.87; N, 3.30\%.

\section{De-coordination of optically pure ligand $\mathrm{L}^{1}$}

The chiral diastereomer $2^{\mathrm{a}}$ (369 $\mathrm{mg}, 0.5 \mathrm{mmol}$ ) and the ligand dppe (231 $\left.\mathrm{mg}, 0.5 \mathrm{mmol}\right)$ were dissolved in $15 \mathrm{ml}$ of $\mathrm{CH}_{2} \mathrm{Cl}_{2}$. The resulting yellow solution was stirred for $1 \mathrm{~h}$. The solvent was removed in vacuo and the crude product was purified by flash chromatography under argon over silica gel by use of a $\mathrm{Et}_{2} \mathrm{O}$ /pentane mixture in a $1 / 10$ ratio $\left(\mathrm{R}_{\mathrm{f}}=0.8\right)$. The ligand was obtained as a white powder with a $98 \%$ e.e. $(175 \mathrm{mg}, 92 \%) .[\alpha]_{\mathrm{D}}=-28^{\circ}\left(\mathrm{c}=0.41, \mathrm{CHCl}_{3}\right)$. The $(R)$ configuration was established from the X-ray structure of the related palladium dichloride complex $\mathbf{8}^{\mathbf{a}}$.

\section{Preparation and crystallization of $\operatorname{PdCl}_{2}\left[(R)-\mathrm{Ph}_{2} \mathrm{PCH}_{2} \mathrm{CH}(\mathrm{Ph}) \mathrm{NHPh}-\mathrm{K}^{2}-P, N\right],\left(8^{\mathrm{a}}\right)$}

The preparation and the characterisation of the racemic complex $\left[\mathrm{PdCl}_{2}\left\{\mathrm{Ph}_{2} \mathrm{PCH}_{2} \mathrm{CH}(\mathrm{Ph}) \mathrm{NHPh}\right.\right.$ $\mathrm{P}, \mathrm{N}\}$ ] was previously published. ${ }^{10}$ According to the procedure, complex $\mathbf{8}^{\mathrm{a}}$ was synthesized from $\mathrm{PdCl}_{2}(\mathrm{COD})$ complex (16.6 mg, $0.06 \mathrm{mmol}$ ) and optically pure $\mathbf{L}^{\mathbf{1}}$ ligand (24.4 mg, $\left.0.06 \mathrm{mmol}\right)$. The mixture was dissolved in $5 \mathrm{ml}$ of toluene and heated at $120^{\circ} \mathrm{C}$ for $1 \mathrm{~h}$. The resulting yellowgreen suspension was filtered and the isolated green solid was washed twice with $4 \mathrm{ml}$ of pentane. 
After extraction with $5 \mathrm{ml}$ of $\mathrm{CH}_{2} \mathrm{Cl}_{2}$, a yellow solution was obtained, which was concentrated to half volume in vacuo. Addition and slow diffusion of a pentane layer afforded suitable yellow crystals for the X-ray analysis.

\section{Crystal structure determination of complexes $\left(2^{\mathrm{a}}, 2^{\mathrm{b}}\right)$ and $8^{\mathrm{a}}$}

Intensity data were collected on a Nonius Kappa CCD at 110K. The structures were solved by the heavy atom method and refined by full-matrix least-squares methods ${ }^{33}$ with the aid of the WINGX program. ${ }^{34}$ Non-hydrogen atoms were anisotropically refined. Hydrogen atoms were included in calculated positions and refined with a riding model. The Flack parameters converged to 0.06(4) for 2 and 0.00(4) for 8 (respectively 0.95(4) and 1.00(4) for the inverted configurations). Crystallographic data and selected bond lengths and angles for $\left(\mathbf{2}^{\mathbf{a}}, \mathbf{2}^{\mathbf{b}}\right)$ and $\mathbf{8}^{\mathbf{a}}$ are reported respectively in Tables $\mathbf{1}, \mathbf{2}$ and 3. CCDC 258376 for $\left(\mathbf{2}^{\mathbf{a}}, \mathbf{2}^{\mathbf{b}}\right)$ and 258377 for $\mathbf{8}^{\mathbf{a}}$ contain the supplementary crystallographic data for this paper. These data can be obtained free of charge via the World Wide Web (or from the Cambridge Crystallographic Data Centre, 12 Union Road, Cambridge CB21EZ, UK; fax: (+44)1223-336-033 or emailing deposit@ccdc.cam.ac.uk).

\section{References}

(1) Gravilov, K. N.; Polosukhin, A. I. Russ. Chem. Rev. 2000, 69, 661-682.

(2) Thompson, S. M.; Stöhr, F.; Sturmayr, D.; Kickelbick, G.; Schubert, U. J. Organomet. Chem 2003, 686, 183-191.

(3) Gao, J.-X.; Ikariya, T.; Noyori, R. Organometallics 1996, 15, 1087-1089.

(4) Yamada, I.; Ohkouchi, M.; Yamaguchi, M.; Yamagishi, T. J. Chem. Soc,. Perkin Trans. 1 1997, 12, 1869-1873.

(5) Dahlenburg, L.; Götz, R. Inorg. Chim. Acta 2004, 357, 2875-2880.

(6) Anderson, J. C.; Cubbon, R. J.; Harling, J. D. Tetrahedron: Asymmetry 2001, 12, 923-935.

(7) Issleib, K.; Rieschel, R. Chem. Ber. 1965, 98, 2086-2090.

(8) Rauchfuss, T. B.; Clements, J. L.; Agnew, S. F.; Roundhill, D. M. Inorg. Chem. 1977, 16, $775-778$.

(9) Maerkl, G.; Merkl, B. Tetrahedron Lett. 1983, 24, 5865-5868.

(10) Andrieu, J.; Camus, J.-M.; Dietz, J.; Richard, P.; Poli, R. Inorg. Chem. 2001, 40, 1597-1605.

(11)Hayashi, T.; Konishi, M.; Fukushima, M.; Kanehira, K.; Hioki, T.; Kumada, M. J. Org.

Chem. 1983, 48, 2195-2202. 
(12) Anderson, J. C.; Cubbon, R. J.; Harling, J. D. Tetrahedron: Asymmetry 1999, 10, 28292832.

(13) Saitoh, A.; Uda, T.; Morimoto, T. Tetrahedron: Asymmetry 1999, 10, 4501-4511.

(14)Kubota, H.; Koga, K. Tetrahedron Lett. 1994, 35, 6689-6692.

(15) Andrieu, J.; Baldoli, C.; Maiorana, S.; Poli, R.; Richard, P. Eur. J. Org. Chem. 1999, 30953097.

(16) Katagiri, T.; Takahashi, M.; Fujiwara, Y.; Ihara, H.; Uneyama, K. J. Org. Chem. 1999, 64, 7323-7329.

(17)Camus, J.-M.; Andrieu, J.; Richard, P.; Poli, R. Eur. J. Inorg. Chem. 2004, 1081-1091.

(18)Dunina, V. V.; Kuz'mina, L. G.; Rubina, M. Y.; Grishin, Y. K.; Veits, Y. A.; Kazakova, E. I. Tetrahedron: Asymmetry 1999, 10, 1483-1497.

(19) Albert, J.; Cadena, J. M.; Granell, J.; Muller, G.; Ordinas, J. I.; D., P.; Puerta, C.; Sanudo, C.; Valerga, P. Organometallics 1999, 18, 3511-3518.

(20) Wild, S. B. Coord. Chem. Rev. 1997, 166, 291-311.

(21) Roberts, N. K.; Wild, S. B. J. Am. Chem. Soc. 1979, 101, 6254-6260.

(22)Chatterjee, S.; George, M. D.; Salem, G.; Willis, A. C. J. Chem. Soc., Dalton Trans. 2001, 1890-1896.

(23) Albert, J.; Cadena, J. M.; Granell, J. Tetrahedron: Asymmetry 1997, 8, 991-994.

(24) Albert, J.; Magali Cadena, J.; Delgado, S.; Granell, J. J. Organomet. Chem 2000, 603, 235239.

(25) Fuchita, Y.; Yoshinaga, K.; Ikeda, Y.; Kinoshita-Kawashima, J. J. Chem. Soc., Dalton Trans. 1997, 2495-2499.

(26)Pabel, M.; Willis, A. C.; Wild, S. B. Inorg. Chem. 1996, 35, 1244-1249.

(27) Bondi, A. J. Phys. Chem. 1964, 68, 441-451.

(28)Camus, J. M.; Andrieu, J.; Richard, P.; Poli, R.; Baldoli, C.; Maiorana, S. Inorg. Chem. 2003, 42, 2384-2390.

(29) Wehman-Ooyevaar, I. C. M.; Grove, D. M.; Kooijman, H.; Van der Sluis, P.; Spek, A. L.; Van Koten, G. J. Am. Chem. Soc. 1992, 114, 9916-9924.

(30)Dunina, V. V.; Golovan, E. B.; Gulyukina, N. S.; Buyevich, A. V. Tetrahedron: Asymmetry 1995, 6, 2731-2746.

(31) Alcock, N. W.; Hulmes, D. I.; Brown, J. M. J. Chem. Soc., Chem. Comm. 1995, 395-397.

(32)Cross, G.; Vriesema, B. K.; Boven, G.; Kellog, R. M.; van Bolhuis, F. J. Organomet. Chem. 1989, $370,357-381$.

(33) Sheldrick, G. M. SHELX97 (Includes SHELXS97 and SHELXL97), Release 97-2, Programs 
for Crystal Structure Analysis; University of Göttingen: Göttingen, Germany, 1998.

(34)Farrugia, L. J. J. Appl. Crystallogr. 1999, 32, 837-838. 
Table 1. Crystal data and structure refinement for palladium complexes $\left(\mathbf{2}^{\mathbf{a}}, \mathbf{2}^{\mathbf{b}}\right)$ and $\mathbf{8}^{\mathbf{a}}$

\begin{tabular}{|c|c|c|}
\hline Formula & $\begin{array}{c}\left(\mathbf{2}^{\mathbf{a}}, \mathbf{2}^{\mathbf{b}}\right) \\
2\left(\mathrm{C}_{34} \mathrm{H}_{34} \mathrm{~N}_{2} \mathrm{PCIPd}\right)\end{array}$ & $\frac{\mathbf{8}^{\mathbf{a}}}{\mathrm{C}_{2} \mathrm{H}_{2} \mathrm{NPCl}_{2} \mathrm{Pd}_{2} \mathrm{CH}_{2} \mathrm{Cl}_{2}}$ \\
\hline M & $\begin{array}{l}2\left(\mathrm{C}_{34} \mathrm{H}_{34} \mathrm{~N}_{2} \mathrm{PC} \mathrm{P} \mathrm{P}\right) \\
1286.9\end{array}$ & $\begin{array}{l}\mathrm{C}_{26} \mathrm{H}_{24} \mathrm{NPCl}_{2} \mathrm{Pd} .2 \mathrm{CH}_{2} \mathrm{Cl}_{2} \\
728.58\end{array}$ \\
\hline $\mathrm{T} ; \mathrm{K}$ & $110(2)$ & $110(2)$ \\
\hline Crystal system & monoclinic & monoclinic \\
\hline Space group & $\mathrm{P} 2_{1}$ & $\mathrm{P} 2_{1}$ \\
\hline $\mathrm{a} ; \mathrm{A}$ & $11.3920(5)$ & $12.9467(4)$ \\
\hline $\mathrm{b} ; \AA$ & $14.1080(7)$ & $15.1518(5)$ \\
\hline c; $\AA$ & $18.1920(9)$ & $15.8284(6)$ \\
\hline$\beta ;{ }^{\circ}$ & $94.623(2)$ & $103.404(1)$ \\
\hline $\mathrm{V}: \AA^{3}$ & $2914.3(2)$ & $3024.23(18)$ \\
\hline $\mathrm{Z}$ & 2 & 4 \\
\hline$F(000)$ & 1320 & 1460 \\
\hline$D_{\text {calc }} ; \mathrm{g} / \mathrm{cm}^{3}$ & 1.467 & 1.598 \\
\hline diffractometer & Enraf-Nonius KappaCCD & Enraf-Nonius KappaCCD \\
\hline scan type & mixture of $\phi$ rotations and $\omega$ scans & mixture of $\phi$ rotations and $\omega$ scans \\
\hline$\lambda ; \AA$ & 0.71073 & 0.71073 \\
\hline$\mu ; \mathrm{mm}^{-1}$ & 0.81 & 1.216 \\
\hline Crystal size; $\mathrm{mm}^{3}$ & $0.37 \times 0.10 \times 0.08$ & $0.37 \times 0.17 \times 0.05$ \\
\hline $\sin (\theta) / \lambda \max ; \AA^{-1}$ & 0.65 & 0.65 \\
\hline Index ranges & h: $0 ; 14$ & h: $-16 ; 16$ \\
\hline & $\mathrm{k}:-16 ; 18$ & $\mathrm{k}:-18 ; 19$ \\
\hline & $1:-23 ; 23$ & 1: $-20 ; 20$ \\
\hline Absorption correction & SCALEPACK & SCALEPACK \\
\hline $\mathrm{RC}=$ Refl. Collected & 11674 & 12401 \\
\hline $\mathrm{IRC}=$ independent $\mathrm{RC}$ & 11674 & 12401 \\
\hline $\mathrm{IRCGT}=\mathrm{IRC}$ and $[\mathrm{I}>2 \sigma(\mathrm{I})]$ & 9452 & 9751 \\
\hline Refinement method & Full-matrix L.S. on $\mathrm{F}^{2}$ & Full-matrix L.S. on $\mathrm{F}^{2}$ \\
\hline Data / restraints / parameters & $11674 / 0 / 703$ & $12401 / 1 / 668$ \\
\hline $\mathrm{R}$ for IRCGT & $\mathrm{R} 1^{\mathrm{c}}=0.0431, \mathrm{wR} 2^{\mathrm{d}}=0.0930$ & $\mathrm{R} 1^{\mathrm{c}}=0.0702, \mathrm{wR} 2^{\mathrm{d}}=0.1658$ \\
\hline $\mathrm{R}$ for IRC & $\mathrm{R} 1^{\mathrm{c}}=0.0603, \mathrm{wR} 2^{\mathrm{d}}=0.1013$ & $\mathrm{R} 1^{\mathrm{c}}=0.0968, \mathrm{wR} 2^{\mathrm{d}}=0.1815$ \\
\hline Absolute structure parameter & $0.05(4)$ & $0.00(4)$ \\
\hline Goodness-of-fit ${ }^{\mathrm{e}}$ & 1.022 & 1.033 \\
\hline Largest diff. peak and hole; e. $\AA^{-3}$ & 0.637 and -0.904 & 3.849 and -1.14 close to $\mathrm{Pd}$ atom \\
\hline
\end{tabular}

${ }^{\mathrm{c}} \mathrm{R} 1=\Sigma\left(\left\|\mathrm{F}_{\mathrm{o}}|-| \mathrm{F}_{\mathrm{c}}\right\|\right) / \Sigma\left|\mathrm{F}_{\mathrm{o}}\right| \cdot{ }^{\mathrm{d}}{ }_{\mathrm{w}} \mathrm{R} 2=\left[\Sigma \mathrm{w}\left(\mathrm{F}_{\mathrm{o}}{ }^{2}-\mathrm{F}_{\mathrm{c}}{ }^{2}\right)^{2} / \Sigma\left[\mathrm{w}\left(\mathrm{F}_{\mathrm{o}}{ }^{2}\right)^{2}\right]^{1 / 2}\right.$ where $\mathrm{w}=1 /\left[\sigma^{2}\left(\mathrm{Fo}^{2}\right)+(0.04 \mathrm{P})^{2}+3.9 \mathrm{P}\right]$ for 2 and $\mathrm{w}=1 /\left[\sigma^{2}\left(\mathrm{Fo}{ }^{2}\right)+(0.1 \mathrm{P})^{2}+8.9 \mathrm{P}\right]$ for 8 where $\mathrm{P}=\left(\operatorname{Max}\left(\mathrm{Fo}^{2}, 0\right)+2 * \mathrm{Fc}^{2}\right) / 3 .{ }^{\mathrm{e}} \mathrm{Goodness}$ of fit $=\left[\Sigma \mathrm{W}\left(\mathrm{F}_{\mathrm{o}}{ }^{2}-\mathrm{F}_{\mathrm{c}}{ }^{2}\right)^{2} /\left(\mathrm{N}_{\mathrm{o}}-\mathrm{N}_{\mathrm{v}}\right)\right]^{1 / 2}$. 
Table 2 Selected bond lengths $(\AA)$ and bond angles $\left({ }^{\circ}\right)$ for complex $\left(\mathbf{2}^{\mathbf{a}}, \mathbf{2}^{\mathbf{b}}\right)$

Bond lengths:

$\begin{array}{llll}\text { Pd-C }(1) & 2.007(8) & \mathrm{Pd}^{*} \mathrm{C}\left(1^{*}\right) & 2.023(7) \\ \mathrm{Pd}-\mathrm{N}(1) & 2.096(6) & \mathrm{Pd}^{*}-\mathrm{N}\left(1^{*}\right) & 2.089(7) \\ \mathrm{Pd}-\mathrm{P} & 2.251(2) & \mathrm{Pd}^{*} \mathrm{P}^{*} & 2.263(2) \\ \mathrm{Pd}-\mathrm{Cl} & 2.420(2) & \mathrm{Pd}{ }_{-} \mathrm{Cl}{ }^{*} & 2.429(2) \\ \mathrm{N}(1) \ldots \mathrm{Cl}{ }^{*} & 3.426(4) & \mathrm{N}\left(1^{*}\right) \ldots \mathrm{Cl} & 3.629(4)\end{array}$

Bond Angles:

$\begin{array}{llll}\mathrm{C}(1)-\mathrm{Pd}-\mathrm{N}(1) & 81.3(3) & \mathrm{C}\left(1^{*}\right)-\mathrm{Pd}{ }^{*}-\mathrm{N}\left(1^{*}\right) & 82.9(3) \\ \mathrm{C}(1)-\mathrm{Pd}-\mathrm{P} & 99.0(2) & \mathrm{C}\left(1^{*}\right)-\mathrm{Pd}^{*}-\mathrm{P}^{*} & 98.8(3) \\ \mathrm{N}(1)-\mathrm{Pd}-\mathrm{P} & 177.59(19) & \mathrm{N}\left(1^{*}\right)-\mathrm{Pd}^{*}-\mathrm{P}^{*} & 177.65(19) \\ \mathrm{C}(1)-\mathrm{Pd}-\mathrm{Cl} & 168.9(3) & \mathrm{C}\left(1^{*}\right)-\mathrm{Pd}^{*}-\mathrm{Cl}^{*} & 169.9(3) \\ \mathrm{N}(1)-\mathrm{Pd}-\mathrm{Cl} & 88.09(19) & \mathrm{N}\left(1^{*}\right)-\mathrm{Pd}^{*}-\mathrm{Cl}^{*} & 87.60(19) \\ \mathrm{P}-\mathrm{Pd}-\mathrm{Cl} & 91.67(8) & \mathrm{P}^{*}-\mathrm{Pd}^{*}-\mathrm{Cl}^{*} & 90.69(8)\end{array}$

Table 3. Selected bond lengths $(\AA)$ and bond angles $\left(^{\circ}\right)$ for complex $\mathbf{8}^{\mathbf{a}}$

Bond lenghts:

$\begin{array}{llll}\mathrm{Pd}-\mathrm{N} & 2.117(7) & \mathrm{Pd}^{*}-\mathrm{N}^{*} & 2.133(7) \\ \mathrm{Pd}-\mathrm{P} & 2.198(2) & \mathrm{Pd}^{*}-\mathrm{P}^{*} & 2.210(2) \\ \mathrm{Pd}-\mathrm{Cl}(1) & 2.293(2) & \mathrm{Pd}^{*} \mathrm{Cl}\left(1^{*}\right) & 2.302(3) \\ \mathrm{Pd}-\mathrm{Cl}(2) & 2.396(2) & \mathrm{Pd}^{*}-\mathrm{Cl}\left(2^{*}\right) & 2.374(2) \\ \mathrm{N}-\mathrm{C}(1) & 1.517(11) & \mathrm{N}^{*}-\mathrm{C}\left(1^{*}\right) & 1.509(11) \\ \mathrm{P}-\mathrm{C}(2) & 1.837(9) & \mathrm{P}^{*}-\mathrm{C}\left(2^{*}\right) & 1.815(9) \\ \mathrm{C}(1)-\mathrm{C}(2) & 1.536(14) & \mathrm{C}\left(1^{*}\right)-\mathrm{C}\left(2^{*}\right) & 1.520(14)\end{array}$

Bond Angles:

\begin{tabular}{|c|c|c|c|}
\hline N-Pd-P & $85.4(2)$ & $\mathrm{N}^{*}-\mathrm{Pd}^{*} \mathrm{P}^{*}$ & $85.7(2)$ \\
\hline N-Pd-Cl(1) & $172.8(2)$ & $\mathrm{N}^{*}-\mathrm{Pd}^{*}{ }_{-} \mathrm{Cl}(1 *)$ & $175.5(2)$ \\
\hline N-Pd-Cl(2) & $93.3(2)$ & $\mathrm{N}^{*}-\mathrm{Pd}^{*}-\mathrm{Cl}(2 *)$ & $93.7(2)$ \\
\hline P-Pd-Cl(1) & $88.17(9)$ & $\mathrm{P}^{*}-\mathrm{Pd}{ }^{*}-\mathrm{Cl}\left(1^{*}\right)$ & $89.88(9)$ \\
\hline $\mathrm{P}-\mathrm{Pd}-\mathrm{Cl}(2)$ & $171.86(8)$ & $\mathrm{P}^{*}-\mathrm{Pd}^{*}-\mathrm{Cl}\left(2^{*}\right)$ & $176.31(9)$ \\
\hline $\mathrm{Cl}(1)-\mathrm{Pd}-\mathrm{Cl}(2)$ & $93.50(8)$ & $\mathrm{Cl}\left(1^{*}\right)-\mathrm{Pd}^{*}-\mathrm{Cl}\left(2^{*}\right)$ & $90.81(9)$ \\
\hline $\mathrm{C}(1)-\mathrm{N}-\mathrm{Pd}$ & $114.2(5)$ & $\mathrm{C}\left(1^{*}\right)-\mathrm{N}^{*}-\mathrm{Pd}^{*}$ & $113.0(6)$ \\
\hline N-C(1)-C(2) & $107.7(7)$ & $\mathrm{N}^{*}-\mathrm{C}(1 *)-\mathrm{C}\left(2^{*}\right)$ & $108.2(7)$ \\
\hline C(2)-P-Pd & $100.9(3)$ & $\mathrm{C}\left(2^{*}\right)-\mathrm{P}^{*}-\mathrm{Pd}^{*}$ & $101.3(3)$ \\
\hline
\end{tabular}




\section{Caption for Figures}

Figure 1. ORTEP view of $\left(2^{\mathbf{a}}, 2^{\mathbf{b}}\right)$. Thermal ellipsoids are drawn at the $50 \%$ probability level. Hydrogen atoms of phenyl groups are omitted for clarify.

Figure 2. ${ }^{31} \mathrm{P}\left\{{ }^{1} \mathrm{H}\right\}$ NMR spectra of the diastereomeric mixture of $\mathbf{2}^{\mathbf{a}}$ and $\mathbf{2}^{\mathbf{b}}$ from successive crystallizations in hot ethanol (top to bottom).

Figure 3. ORTEP view of complex $\mathbf{8}^{\mathrm{a}}$. Thermal ellipsoids are drawn at the $50 \%$ probability level. Only one molecule is shown for clarify. 
Figure 1

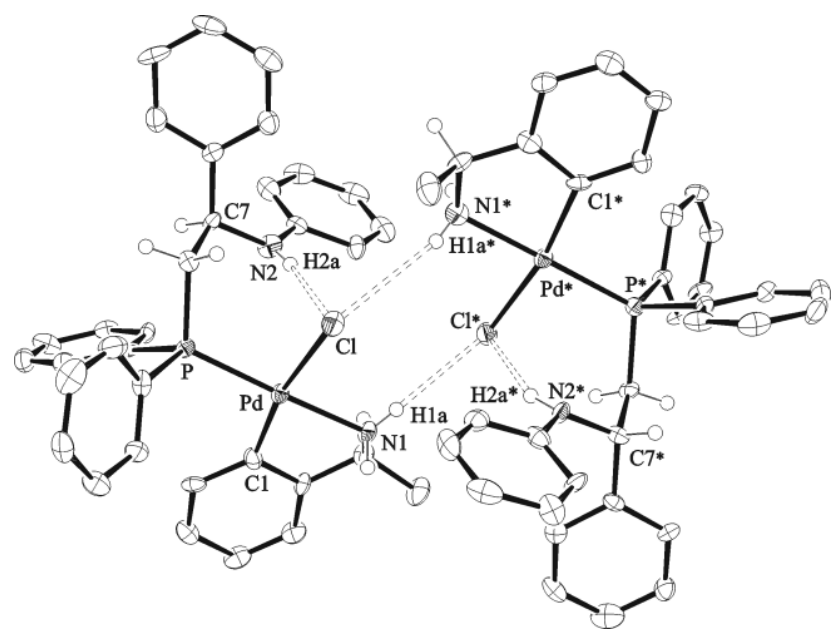

Figure 2

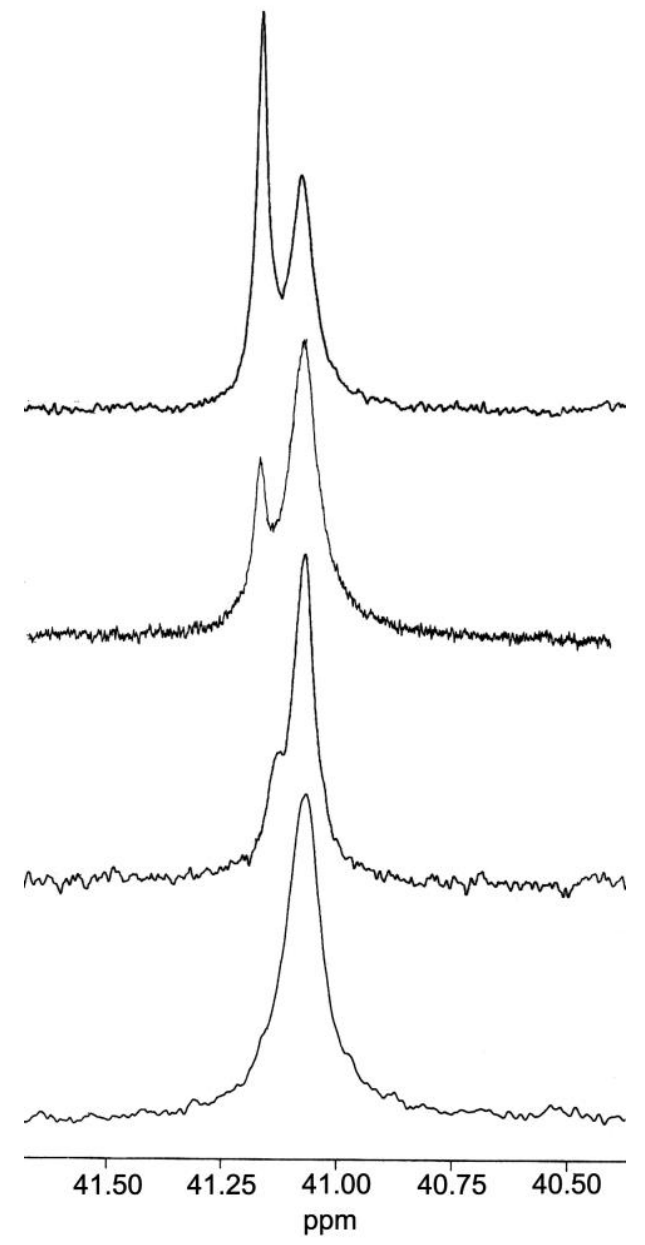


Figure 3

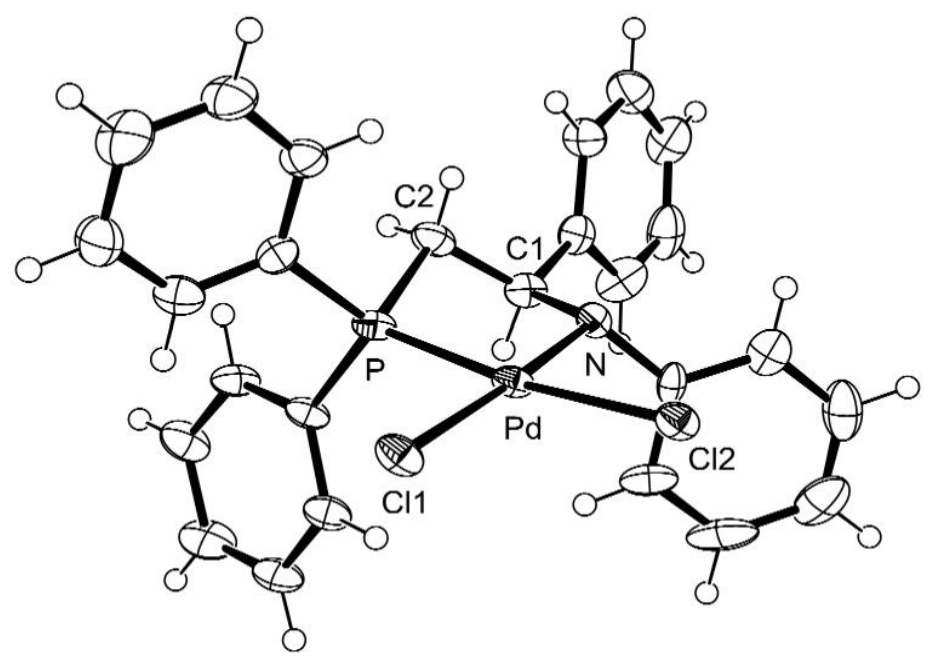


chart 1

${ }_{\mathrm{Ph}} \mathrm{P}_{\mathrm{NHAr}}^{\mathrm{Ph}}$<smiles>Cc1c(C(C)C)cccc1C(C)C</smiles>

\section{Scheme 1}

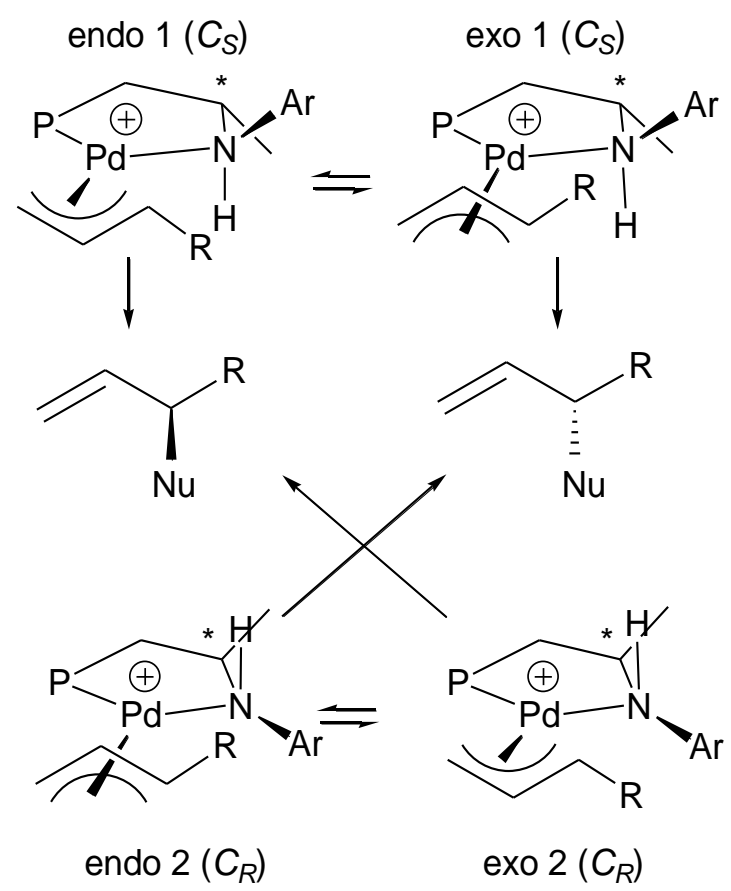

\begin{tabular}{|c|c|c|}
\hline & $\begin{array}{c}\text { endo/exo } \\
\text { (enantioselectivity) }\end{array}$ & $\begin{array}{l}\text { \% trans-P isomers }{ }^{a} \\
\text { (regioselectivity) }\end{array}$ \\
\hline $\mathrm{R}=$ & $1.76\left(\mathrm{~L}^{1}\right) \quad 8.67\left(\mathrm{~L}^{2}\right)$ & $83 \%\left(L^{1}\right) \quad 87 \%\left(L^{2}\right)$ \\
\hline $\mathrm{R}=\mathrm{Ph}$ & $2.50\left(\mathrm{~L}^{1}\right) \quad 1.28\left(\mathrm{~L}^{2}\right)$ & $79 \%\left(L^{1}\right) \quad 16 \%\left(L^{2}\right)$ \\
\hline
\end{tabular}

${ }^{a} \mathrm{R}$ group is in trans position vs $\mathrm{P}$ and cis- $\mathrm{P}$ isomers are omitted for clarify. 
Scheme 2
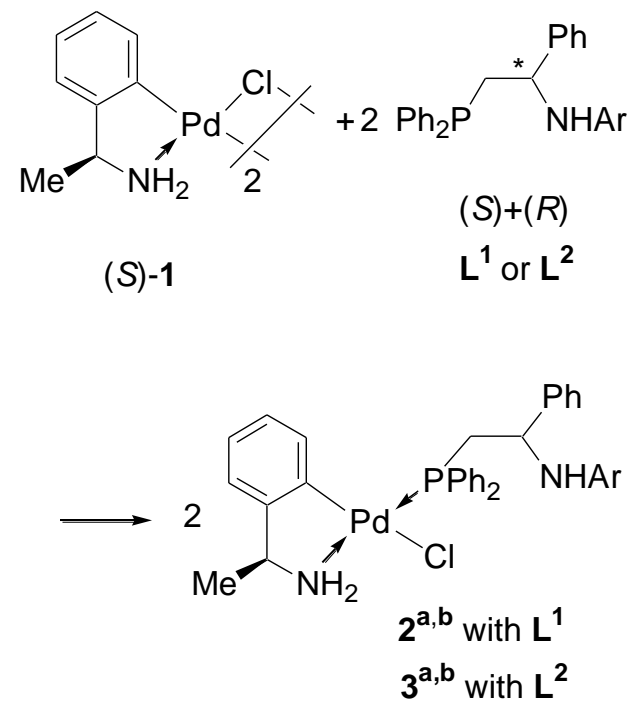

Scheme 3

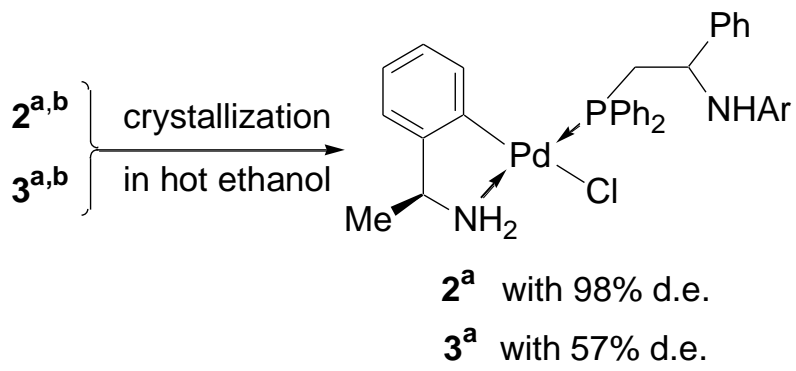

\section{Scheme 4}

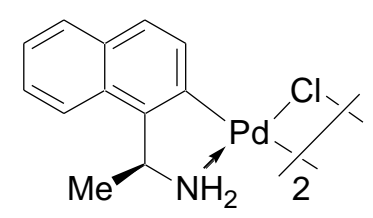

(S)-4

1) $+2 \mathbf{L}^{\mathbf{1}}$
2) in hot
ethanol<smiles>C[C@@H]1N[P@@](Cl)(P(CC(Nc2ccccc2)c2ccccc2)c2ccccc2)c2ccc3ccccc3c21</smiles>
$5^{a, b}$ no d.e. 
Scheme 5

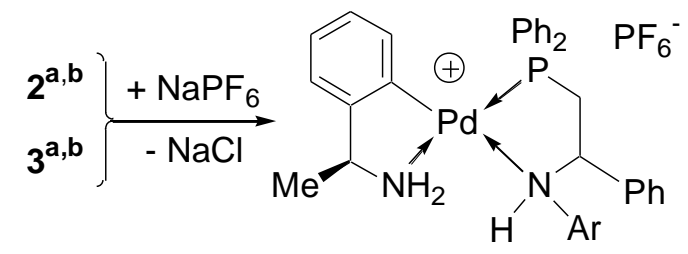

$6^{a, b} 0 \%$ d.e.

(12\% d.e. after crystallizations)

$7^{\mathrm{a}, \mathrm{b}} 0 \%$ d.e.

( $27 \%$ d.e. after crystallizations)

\section{Scheme 6}<smiles>C[C@@H]1N[P@@](Cl)(P(=O)(CC(Nc2ccccc2)c2ccccc2)c2ccccc2)c2ccccc21</smiles>

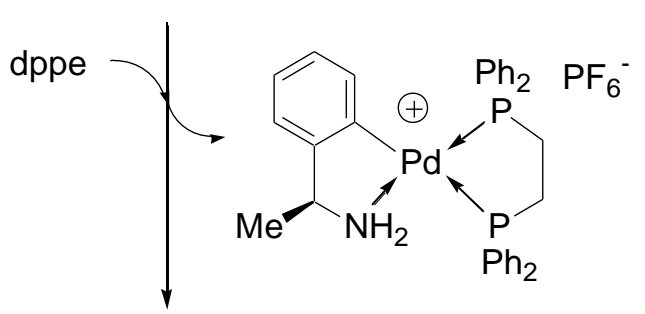<smiles>Pc1ccccc1</smiles>

$98 \%$ e.e. $(R$ or $S)$

\section{Scheme 7}

$\mathrm{Ph}_{2} \mathrm{P} \overbrace{\mathrm{NHPh}}^{\mathrm{Ph}} \frac{+\left[\mathrm{PdCl}_{2}(\mathrm{COD})\right]}{-\mathrm{COD}}$ $98 \%$ e.e. ( $R$ or $S)$

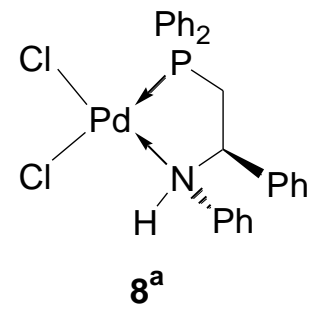

